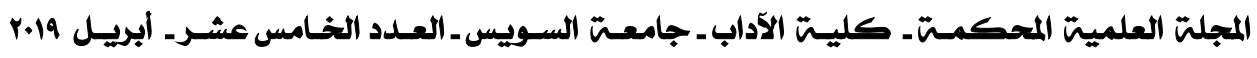

\title{
السياق بين البلاغة العربية والنظرية التداولية في خطب سيدنا عمر بن الخطاب
}

\author{
م. ولائ محمد إبراهييم أبو الخير \\ معيدة بقسم اللغت العربيت كليت الآدابد جامعت السويس الهريس
}




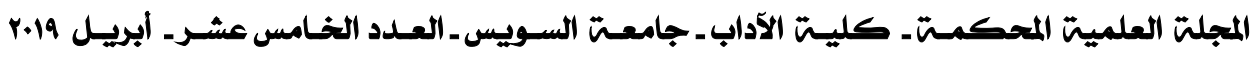


تَهتم الدر اسات التداولية بالجانب التَواصلي بين البشر؛ وكيفيــة اســتـعمال

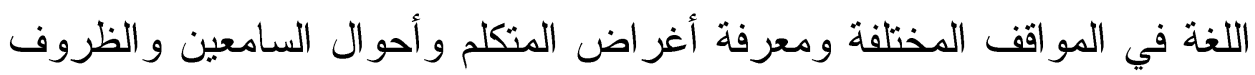
المحيطة بهم فهي "علم جديد للتو اصل يسمح بوصف وتحليل وبناء استر اتيجيات التخاطب اليومي و المتخصص بين المتكلمين في ظروف مختلفةٍ"' وكذلك ركزت البلاغة العربية على الجانب التواصلي بين البشر؛ وكيفية إبلاغ و إيصال الكــلام إلى ذهن السامع من جهة المتكلم؛ فالبلاغة في اللغة تدل على الوصول والانتهاء

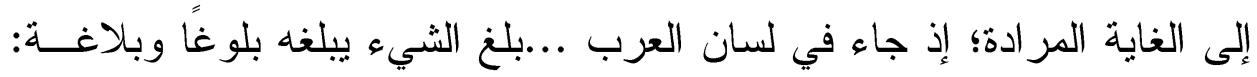
توصل و انتهى وتبلغ الثيء: وصل إلى مر اده، و البلاغ ما يتبلغ به؟ ويتوصـلـ

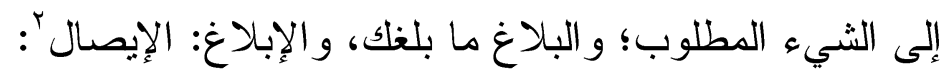
ومن هنا تبدو العلاقة و اضحة بين البلاغة التي ترمي إلى التو اصل وبــين التذاولية التي تدرس أقطاب عملية التو اصل من: رسالة مرسيل مرست إليه

ويمثل المرسيل(المتكلم) و المرسل إلبه(المتلقي) قطبيْ عملية الاتصال؛ لأن أي خطاب بصفة عامة لا يقوم على أحدهما دون الآخر؛ فالمتكلم له دور خاص وله في عملية التواصل أثناء الكلام؛ إذ لابد أن يكون صاحب قدرة بلاغية تؤدي إلى الى دأل إبلاغ كلامه للسامع و التأثير فيه؛ فهو سيد الموقف الخطابي وكذلك هو المسؤول أولًا و أخيرًا عن الخطاب، ويتصرف فيه بحسب الموقف الخطابي الموجود فيــه، وبحسب وضعية المخاطب وخلفيته عن هذا الموقف، و المتلقي هو مكمّل ومــتمّم

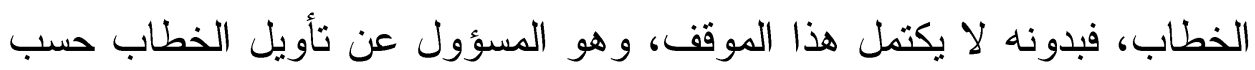
المناسبة التى قيل فيها، و الخطاب هنا هو الممر الرابط بين الخطيب و المتلقي،

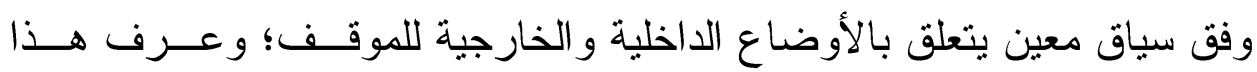
السياق في النظرية التداولية ب(السياق التداولي) إذ إنّه من أهم الأعمدة التداولية؛ و الذي يعتبر أداة إجر ائية تساعد بشكل كبير في تأويل مقاصد المتكلم من جهـــة إنها. ومقاصد المتلقي من جهة أخرى؛ فإنّ أي فهم لخطاب لغوي معين لا بمكن تحقيق 
الغاية منه إلا إذا قمنا بمعرفة الأوضاع السياسية والاجتماعية و التاريخية الخاصة

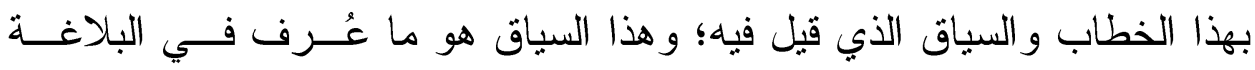
العربية ب (لكل مقام مقال) وتتجلى هنا أهمية هذه الأقطاب في العملية التو اصلية لتحقيق غرض التفاعل و التواصل الفكري، وهذا ما ترمي إليه البلاغة العربيــة و التذاولية وتعمل على معالجته و البحث فيه. و إن تحدثا عن هذه الأوضاع و السياق الذي وجدت فيه فيه فإننا نجد أن خطب (سيدنا عمر بن الخطاب) خير مثال نظهر من خلالها فكرة السياق التـداولي أو فو عُرف في البلاغة العربية بالمقام؛ فالخطابة عامة وسيلة أساسية لإيصال الأفكار وتحقيث الأهداف السياسية والاجتماعية والإنسانية والأدبية، و المقاصد الحوارية؛

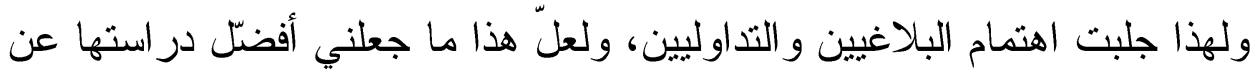
باقي النصوص الأدبية؛ فقد أثنارت الخطابة اهتمامي دون غيرها من الصناعات الكلامية، لأنها تعتبر طريقة مثلى للحوار و التحاور بين أفراد العملية التواصلية،

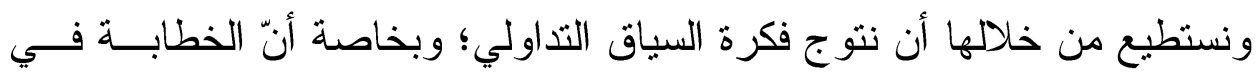
عهد الفاروق شهدت ازدهارًا كبيرًا بفضل ما تميّز به من فصاحة لسان، و عرض بيان، وسرعة بديهة، فتميزت خطبه بالتتوع و الشمول وذلك بتعدد سياقات القول ومقاماتها بحسب ما تقتضيه الحاجة وحال المسلمين أثثاء إلقائه للخطبــة، فكـــان نتاج ذلك كم هائل من الخطب التي برهنت على أنه خطيبًا من الدرجة الأولـى

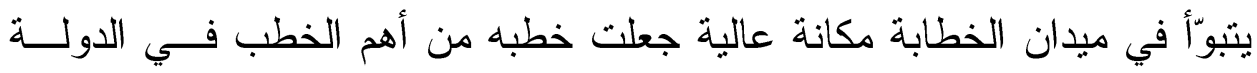
الإسلامية، لاشتمالها على الخطب الدينية و السياســية و الاجتماعيــة و الإنســانية و المقاصد الحوارية بينه وبين المسلمين.

وكما التقت التداولية مع البلاغة العربية من خلال فكرة التو اصل اللغوي؛ فنلاحظ ارتباطهما من خلال نقطة رئيسية أخرى ألا وهى مبدأ الإفادة، ونود أن أن أنها نشير إلى أن هذا المبدأ تحقق من خلال فرع من فــروع البلاغـــة العربيـــة ألا و هو (علم المعاني) الذي تتاول تعريفه كثير من علماء البلاغة العربية؛ وســوف كـ نحاول من خلال التعريف توضيح مبدأ الإفادة الذى يربط بين التداولية وبين علم 
المعاني وهذا التعريف هو تعريف ابن خلدون لعلم المعاني "هذا العلم هو الحادث

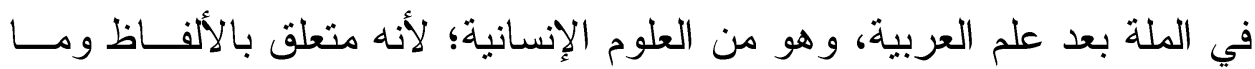

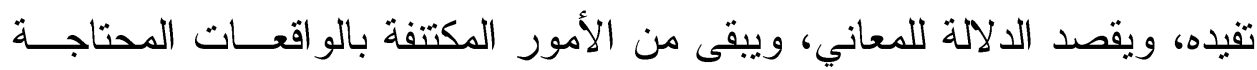

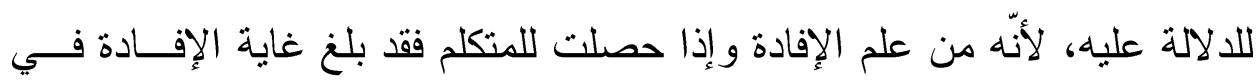
كلامه؛ و إذا لم تشتمل عليه منها؛ فليس من جنس كلام العرب، فإن كلامه و اسع،

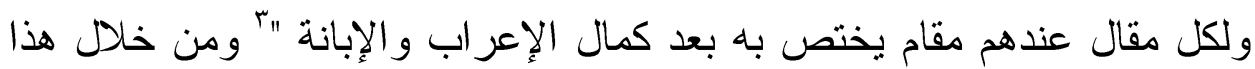

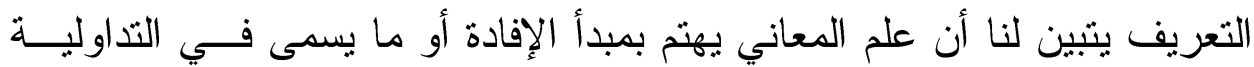
بمبدأ القصد؛ وقد ركز علماء البلاغة اهتمامهم بهذا المبدأ مـن خــلال مبحــــ

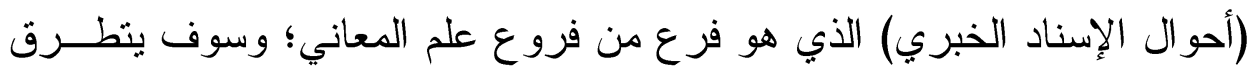
البحث إلى الربط بين البلاغة العربية وبين التداولية من خلال هذا المبحث فقط،

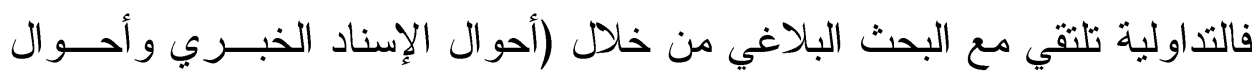

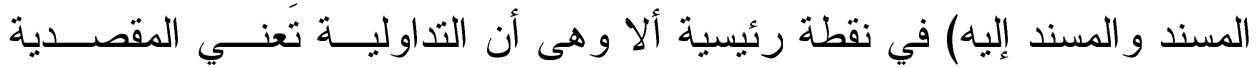
وكذلك أحو ال الإسناد الخبري و أحوال المسند و المسند إليه من (ذكـــر وحـــف وتقديم وتأخير وتعريف وتتكير) لكل حال من هذه الأحو ال مقصد وغرض ونحن نبحث عن المقصد والغرض وهذا هو صميم عمل التداولية."والمقاصد التـي لا تتعلق بالوضع ؛ فإنها تتعلق بالسياق و النسق وما ينتج عن ذلك من معانِ جديدة، فيها تفاوت عن وضعها التي كانت فيه ، وبذلك تثتوع الأغر اض و المعـاني ولا تقف عند حد، وهذا مرتبط بغاية المتفنن، وقبول المتلقي وما تثيره في نفسه تلك

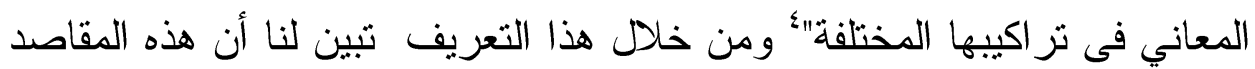

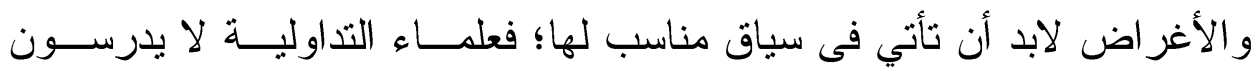
الألفاظ و المعاني بمعزل عن سباقها الكلامي و الحالي؛ كما أنهّم لا يدرسونها بعيدّا عن أغر اض المتكلم ومقاصده. من خلال ما سبق سنحاول الربط بين السياق التداولي وبين أحوال الخبــر من حيث التوكيد وعدمه(أضرب الخبر)؛ والتطبيق على خطب سيدنا عمر بـن إنـ الخطاب، ولكن قبل هذا نود أنْ نشير: 
إلى أنّ البلاغيين قسموا الإسناد الخبري بالنظر إلي المخاطَــبـ وحالتــهـ النفسية وحركته الذهنية إلى ثلاثة أقسام:

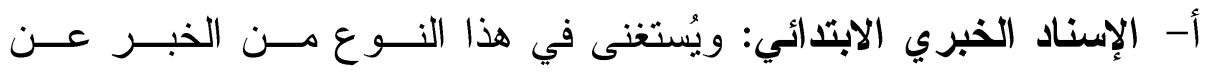
المؤكدات التي تقوي الحكم الإسنادي لأنه يلقى إلى مخاطَب خالي الــذهن من الحكم ولبس لديه معرفة بالمعلومات التي سيقدمها المتكلم له. ب-الإسناد الخبري الطلبي: تتسم الجملة الخبرية في هذا النوع بوجود مؤكِد

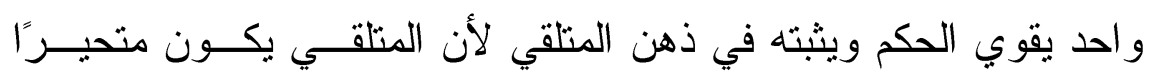

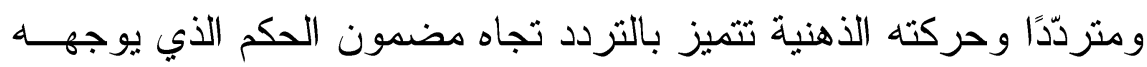
إليه المتكلم، فالمتكلم هنا يكون حريصًا على توصيل الخبر إلى المتلقـي و تأكيده بأداة توكيد ليحقق غايته، فنفس المتلقي تكون مترددة وتحتاج إلى يقين "و إذا ألقاها إلى طالب لها متحير طرفاها عنده دون الاستتاد فهو منه

$$
\text { بيْن بيْن لينقذه عن ورطة الحيرة"ه }
$$

ج-الإسناد الخبري الإنكاري: وهو المستوى الثالث لأحوال الإسناد الخبري من حيث التوكيد، ويتوجّه إلى مخاطَب رافض للحكم وليس لائه قبــــول

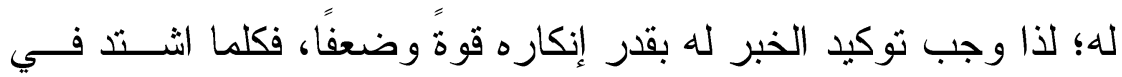

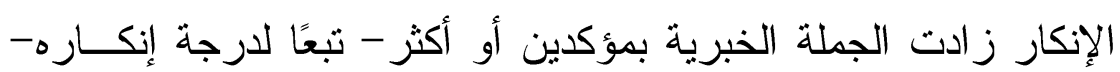
لتقوية الحكم و إقناع المتلقي بقبوله" لإنه

سنتكلم عن مفهوم السياق التداولي ولكي نتوصل إلى مفهومه التــداولي

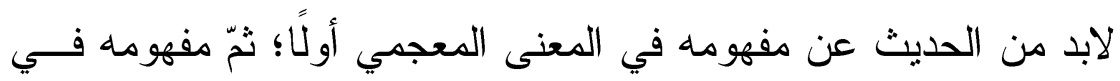
الموروث البلاغي العربي ثانيًا. 


\section{مفهوم (السياق) لفةًّ:}

يُعد المفهوم اللغوي للألفاظ الركن الأساسي في تحديد المعنى الاصطلاحي وتوضيحه، بل إنه لا يتضح إلا من خلاله؛ وسوف نتناول المفهوم اللغوي للسياق كما ورد في بعض المعاجم. ففي (أساس البلاغة) للزمخشري، يذكر (السياق) قائلاً: "يســوق الحــديث

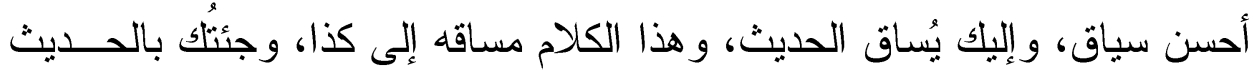

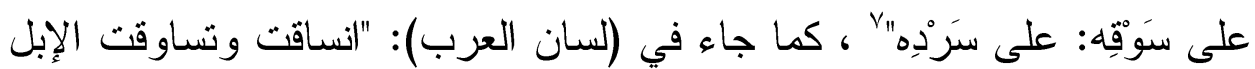

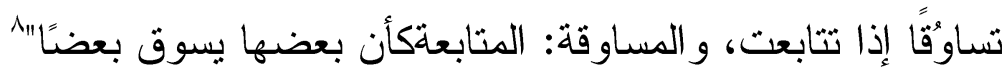
ومن هنا يتضح أنّ مفهوم السياق في المعجم يدور حول عرض الحـديث

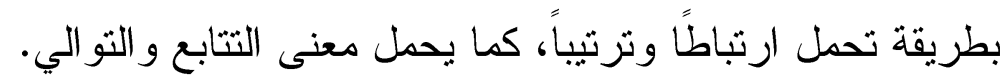

\section{مفهوم (السبياق) بلاغثيًا:}

عرف البلاغيون العرب فكرة (السياق) من خلال دراستهم للمقام، أو مــــا عُرف بمقتضى الحال، وكذلك من خلال العبارة الأخرى (لكل كلمة مع صاحبتها مقام) فالمقام لديهم له دور كبير في المعنى فقد اهتدوا في وقت مبكر إلى أهميـــة الإحاطة بملابسات الكلام من ملاحظة للسامع و المقام وظروف المقال وما يقــوم بينهما من رو ابط.

وقد كان الكلام على (مقتضى الحال) من أعمدة البحث البلاغي على مــر

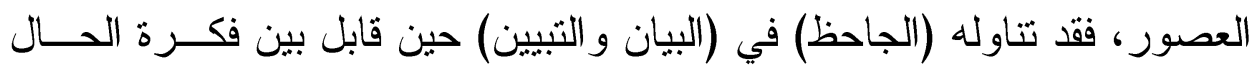
و المقام، وبين أحوال السامع و المتلقي ومقاماتهم الاجتماعية ومتى يكون الكــلام مناسبًا للسياق الذي يُقال فيه "ينبني للمتكلم أن يعرف أقدار المعاني ويوازن بينها وبين أقدار المستمعين....

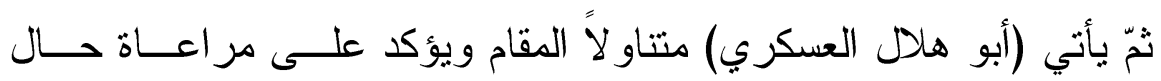

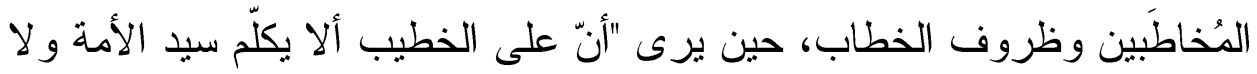
الملوك بكلام السوّة،، لأن ذلك جهل بالمقامات وما يصلح في كل و احد منهما من الكلام و أحسن الذي قال: لكل مقامٍ مقال" بـ 
و استخدم (السكاكي) مصطلح (مقتضى الحال) لمفهوم (السياق) حيث يقول

في كتابه (مفتاح العلوم): "اعلم أنّ علم المعاني هو تتبّع خواص تر اكيب الكــلام في الإفادة وما يتصل بها من الاستحسان وغيره ليحترز بالوقوف عليهــا عـن الخطأ في تطبيق الكلام على ما يقتضي الحال ذكره (...) وكذا، إذا لفظ بالمسند

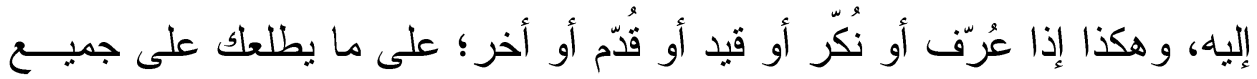

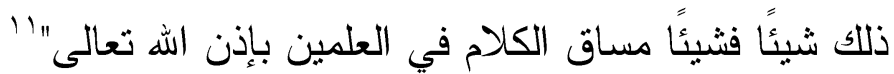

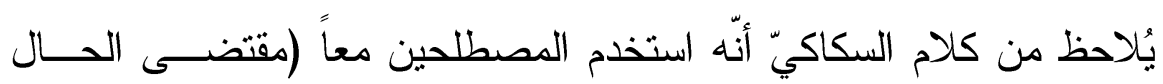
و السياق) فقال (لإحترز عن الخطأ في تطبيق الكلام على ما يقتضي الحال ذكره) وقال أيضًا (على ما يُطلكك مساق الكلام في العلمين) ولفظ (مســاق) (الســياق) بمعنى و احد لأن كلبهما مصدر لعل واحد (ساق يسوق مُساقًا ومَساقًا)

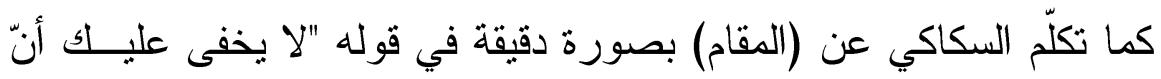
مقامات الكلام متفاوتة، فمقام التشكر يباين مقام الثكاية، ومقام التهنئة يباين مقام التعزية (...) وكذا مقام الكلام مع الذكي يغاير مقام الكلام مع الغبي، ولكلٍ مــن ذلك مقتضى غير مقتضى الآخر" ثم نر اه يتكلم عن قول البلاغيين (لكل كلمة مع صاحبتها مقام) فيقول: "ثم إذا شرعت في الكلام، فكل كلمة مع صاحبتها مقام، ولكل حد ينتهي إليه الكــلام

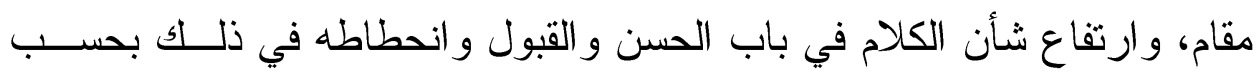

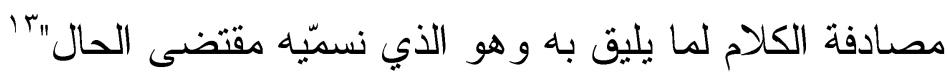

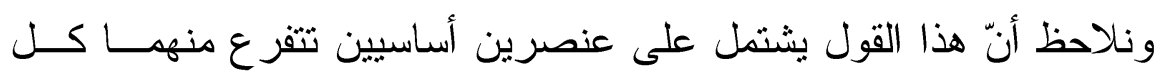

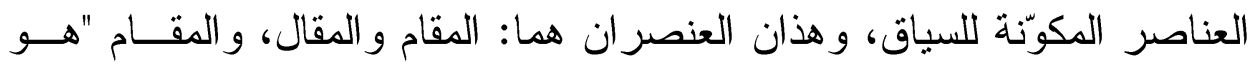

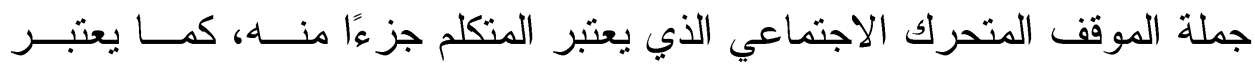

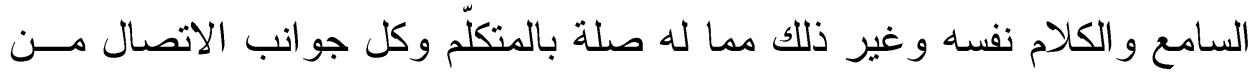

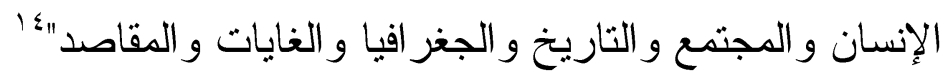

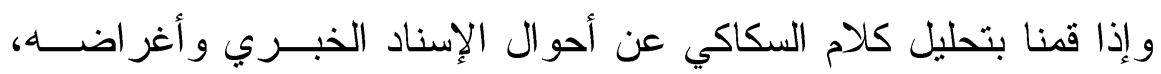

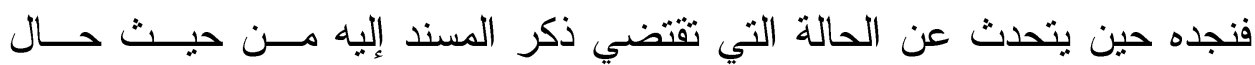




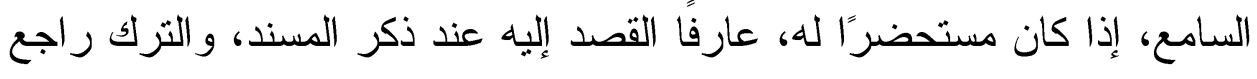
إمّا لضيق المقام (وهو يقصد هنا السياق الخارجي) و إما للاحتراز عن العبث بناء

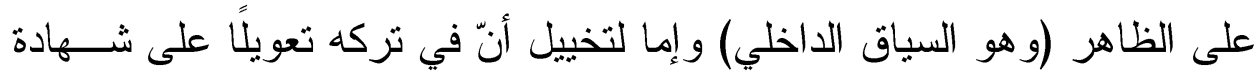
العقل، وفي ذكره تعويلا على شهادة اللفظ من حيث الظاهر (حال السامع) و إمّـــا

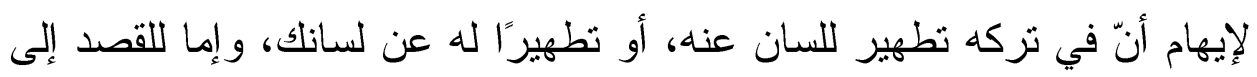
عدم التصريح ليكون للك سبيل إلى الإنكار إن مسّت إليه حاجة (حال المتكلّم) 10

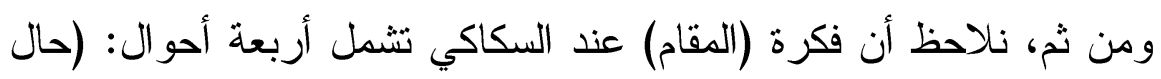

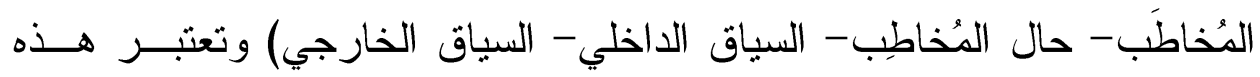

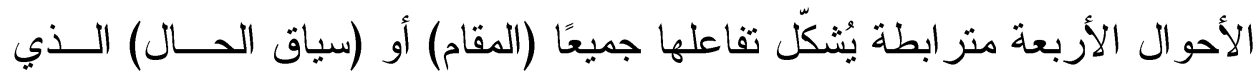
تتحقق ضمنه عملية التو اصل وبمر اعاة السكاكي لهذه الأحو ال تتجلى مر اعاتـهـه

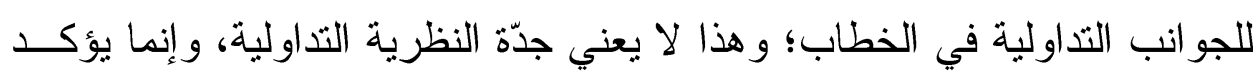

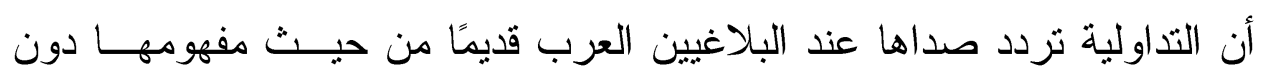
مصطلحها. إذن، اهتمام البلاغيين بمطابقة المقام لمقتضى الحال يثبت البعد التـداولي

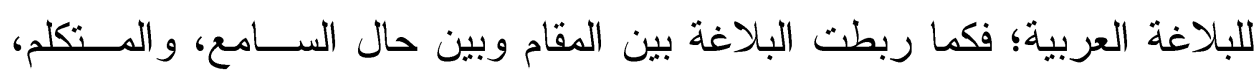
ربطت التداولية بين السياق (المقام) وبين حال السامع و المتكلّ.

\section{السياق التلداولي}

من المفاهيم التداولية التي لاقت نصيبا و افراً مــن الدراســـة والاهتمــام، موضوع (السياق) حيث تستتد عليه اللسانيات التذاولية في در استها للغــة أثنــاء

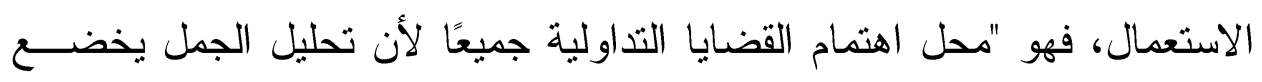
إلى السياق، وكذلك تحليل أفعال الكلام، وقوانين الخطاب، ومســـائل الملفوظيــة و القضايا الحجاجية و غير ها" 17 وقد قسّم المحدثون مصطلح (السياق) إلى مفهوميْن: 
أ- المفهوم البنيوي:ويسمى (السياق اللغوي) أو (السياق الــــاخلي) وكــللك

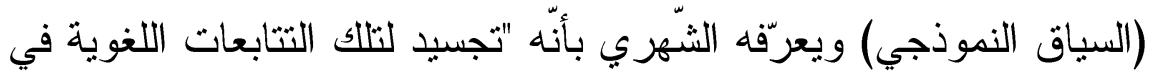

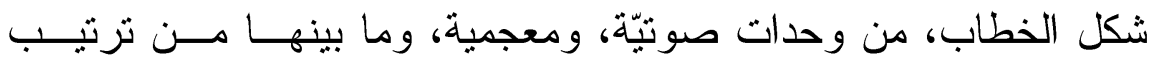

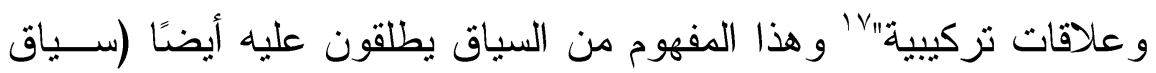

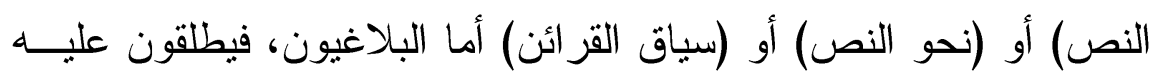

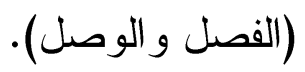
ب- المفهوم التداولي:ويسمى (سياق الموقف) أو (سياق الحـــال) أو (الســياق

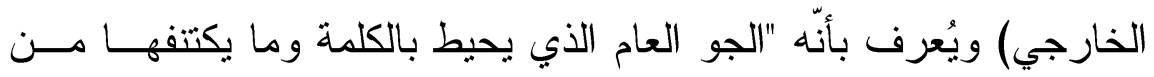

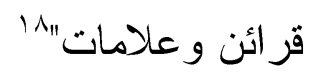

ويمكن أن تختلف السياقات وتتعدد حسب وضعيات الخطـــاب المختلفــة، فهناك أنواع كثيرة من السياقات التي تتاولها علماء التداوليــة أمثــال (بريـــ،

$$
\text { و أولمان، وفيرث، وفر انسواز أرمينكو، و غير هم) }
$$

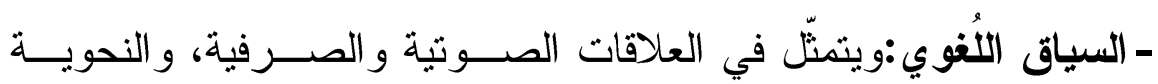

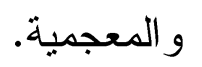

ـ السياق غير اللفوي:ويضم السياق الاجتماعي، و السياق الثقافي، و السياق

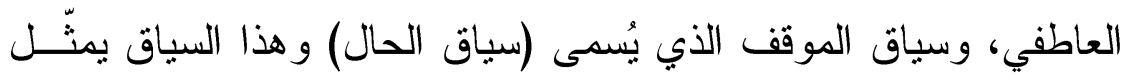

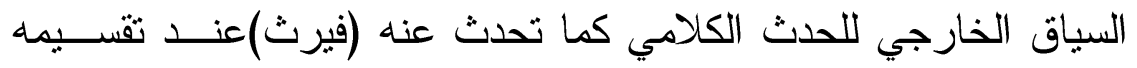

$$
\text { للسياق. }
$$

أمّا (فر انسواز أرمينكو) فقد تتاولت السياق من خلال اعتبارين 19 الأول: وقد أطلقت عليه (التتوّع) وقسّدت السياق فيه بحسب نوعه وحددت كـلـل

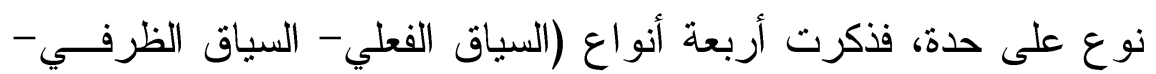
السياق الإحالي أو المرجعي- السياق الوجودي) 
الثاني: و أطلقت عليه (المفهوم الموحدّ) وذكرت أنّ مفهوم السياق مفهوم موحّـد

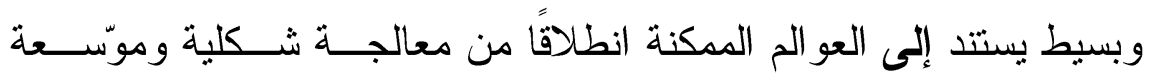

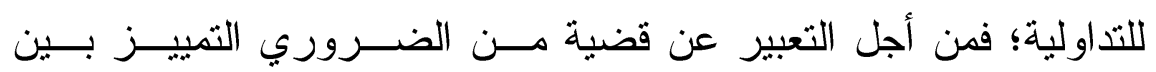
الإمكانيات و هذه المقدرة أساسية لدى المتكلّم لأنّ مجموع العو الم الممكنة المفيدة في مقام معيّن هو المجموع السياقي.

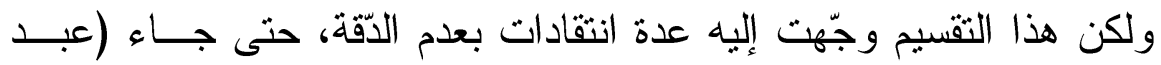
الهادي الشهري) وتحدّث في كتابه (استر اتيجيات الخطاب) عن تقسيم (بريــــ) للسياق، ونقل عنه خمسة أنواع من السياقات يطابقها العدد نفسه من التــــاوليات،

$$
\text { و هذه الأنو اع هي: }
$$

1- السياق النّصي أو سياق القرائن أو نحو النص

$$
\begin{aligned}
& \text { r- السياق الوجودي } \\
& \text { r- السياق المقامي } \\
& \text { ع-سياق الفعل } \\
& \text { 0- السياق النفسي }
\end{aligned}
$$

وذكر أن هذه الأنو اع من السياقات متداخلة ومنز ابطة، فلا يســتغنى أيّ

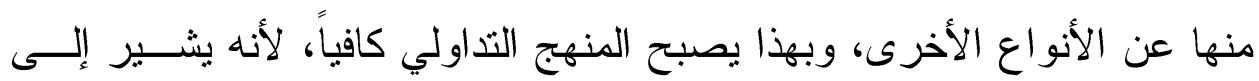

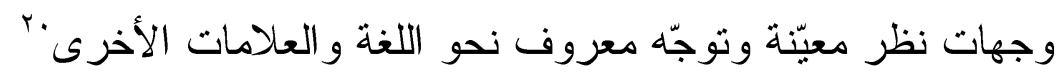

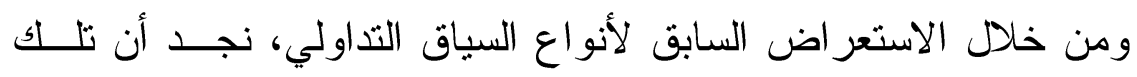
التقسيمات تتاولت (سياق الموقف) كأحد أنواع السياقات التداولية وقد كثر الحديث

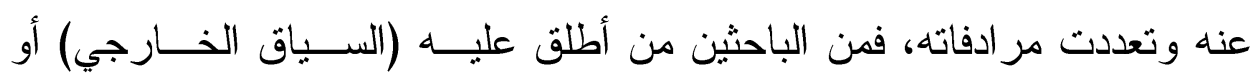

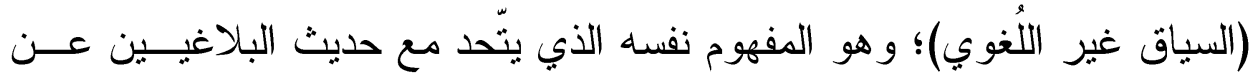

$$
\text { (سياق الحال) أو مصطلح (المقام). }
$$




\section{عناصر (السياق) عند البلاغيين العرب:}

يتكون السباق عند البلاغيين العرب من ثلاثة عناصر أساسية (المتكلّم المخاطَب- الظروف المحيطة بالموقف) وقد تطرق مسعود صحر اوي في كتابه (التداولية عند العرب) إلى آراء البلاغيين العرب حول العناصر الأساسية للسياق في كل خطاب أمثال (عبد القاهر الجرجاني وجلال الدين الســيوطي) واســتتج صحر اوي أنّ البلاغيين العرب فهموا من اللغة أنّها "لفظ معين يؤديه متكلّم معيّن في سياق ومقام معيّن وموجّه إلى مخاطَب معيّن لأداء غرض تو اصلي معـيّن، وليست مجرد منظومة من القواعد الذهنية المجرّدة كما هو الثأن في التصــور

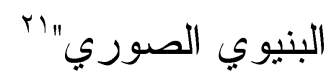
وصنّف التداوليون العناصر المكوّنة لسياق الخطاب إلى ثلاثة أصــناف، هي: (المرسِل، المرسل إليه، السياق الخارجي) و استخدم عبد الهــادي الثــــري مصطلح (العناصر المشتركة) بدلاً من (السياق الخارجي) وقد ذكــر مــن هـــه العناصر العلاقة بين المتخاطبين، و المعرفة المشتركة بينهما. أمّا الدكتور طه عبد الرحمن فذكر أن للسياق عناصر ثناثة، هي: أولاً: العنصر الأتي: ويشمل معتقدات المتكلّمومقاصده و اهنماماته ورغباته. ثانياً: العنصر الموضوعي: أي الوقائع الخارجية (الظروف الزمانية و المكانية) ثالثاً: العنصر الأواتي: ويشمل المعرفة المشتركة Mutual Knowledge بــين المتخاطبين، أو ما بسمى بالأرضية المشتركة Common Ground و هي

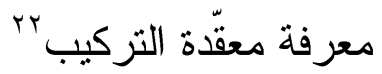

و هذه العناصر وأهمهم العنصر الشخصي الذي يمثله طرفــي الخطــاب

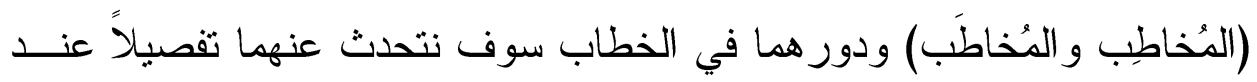
الحديث عن (قطبْيْ العملية التواصلية) بين البلاغة وبين التداولية. 


\section{المخاطب والمخاطَب بين البلاغة وبين التداولية}

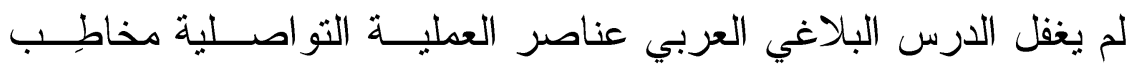

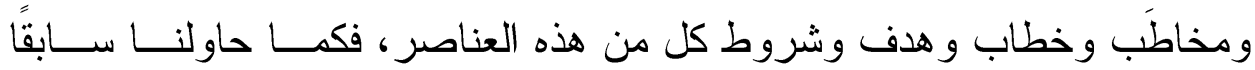
الربط بين بعض المفاهيم التداولية الحديثة وبين فكرة مقتضى الحال في البلاغة العربية، وكذللك الربط بين السياق في اللسانيات التداولية وبين المقولة الثـــيرة

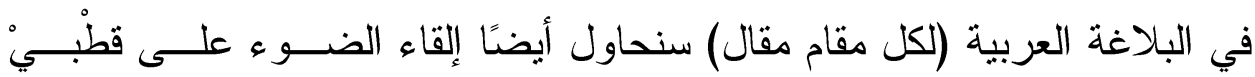
العملية التو اصلية (المخاطَب و المخاطِب) في البلاغة العربية و التداولية. أ-تداولية المُخاطِب في البلاغة العربية:

لو رجعنا إلى تعريف البلاغة الذي يقول "سميت البلاغة بلاغـــة لأنهــا

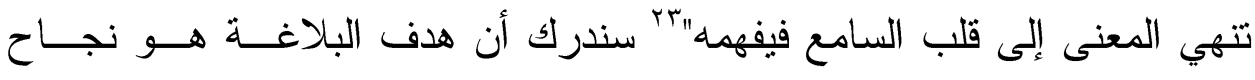

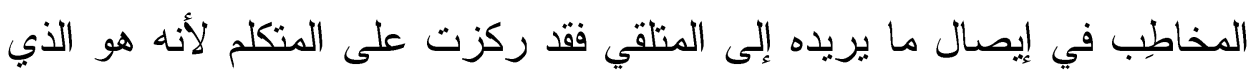
يتصرّف في اللغة ويوظفها لصالحه ولخدمة أهدافه، فالمنكلم هو (فاعل الخطاب)

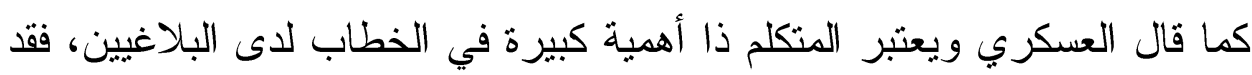

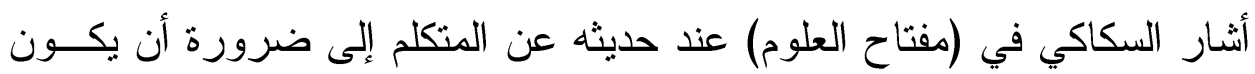

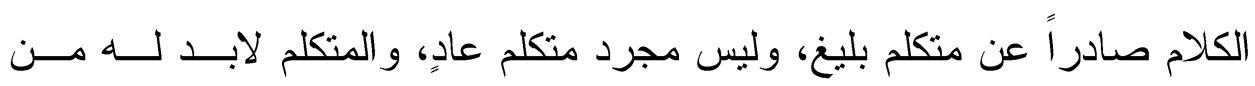

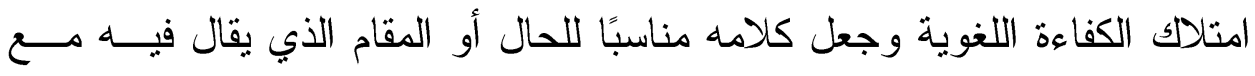

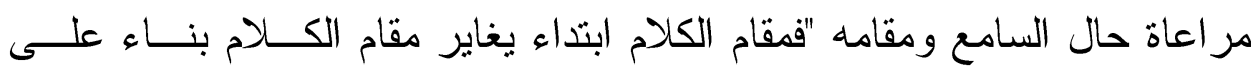

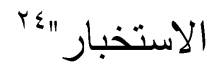

فالمتكلم يسعى إلى التأثير في السامع و إقناعه بكلامه؛ فهـــ المســؤول

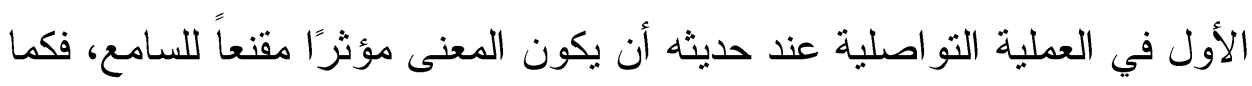

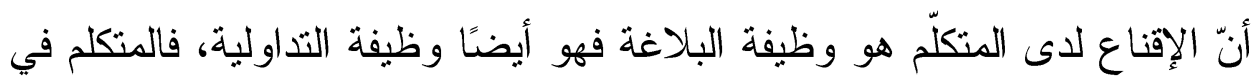

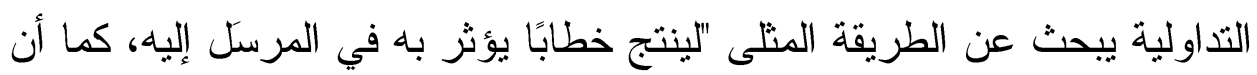

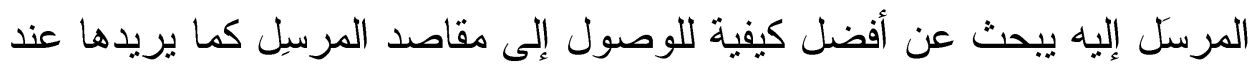

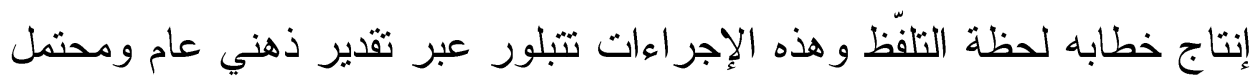

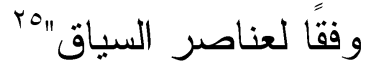


ومن هنا، تشنرك البلاغة مع التداولية في اهتمامهم بالمتكلم ودوره فـي إقناع السامع بمقصده من الرسالة التي يلقيها عليه؛ لكنها تختلف عنها في الإقناع الجمالي وليس مجرد الإقناع التذاولي الخبري النفعي. فقــــ تعـددت الدراســات

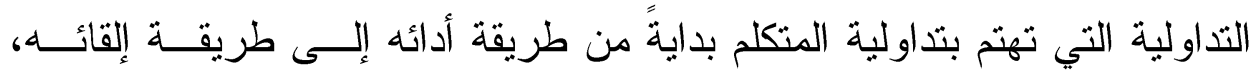

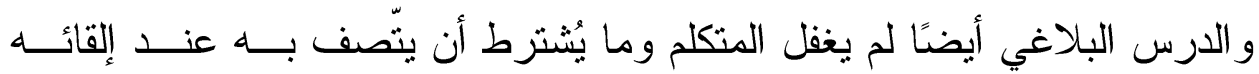
للخطاب وقدرته البلاغية على توظيف قو اعد اللغة. فوجه التداولية في المتكلم "يكمن في أنّه يُنتج كلامًا، هذا الكلام هو الذية الذية

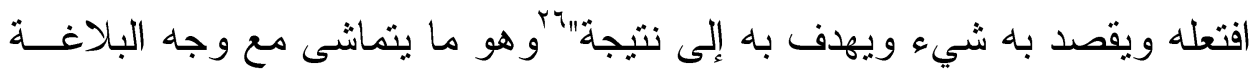
في المتكلم عند استخدامه "للطريقة أو الوسائل المتبعة في الكلام حتى تتفذ معانيه إلى عقل وقلب السامع وما يقتضيه ذلك من وضوح ومحسّنات و إيانه و إظهــار و إقناع" إلى

\section{ب-تداولبة المُخاطَب في البلاغة العربيةة:}

اعتنى البلاغيون بالمخاطَب من خلال بحوثهم حول فكــــة (المقــام) و (مقتضى الحال) فإذا كانت البلاغة هي مطابقة الكلام لمقتضى الحال، فالحال إذًا

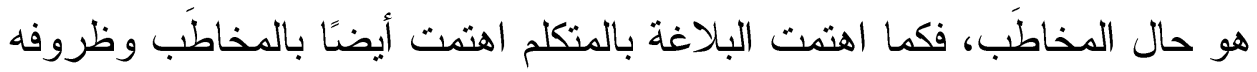

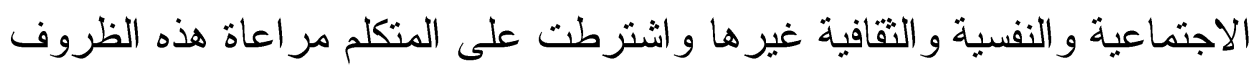
عند إلقائه رسالة على السامع ومر اعاته أيضًا لأقدار وطبقات المستمعين "ينبغي للمتكلم أن يعرف أقدار المعاني ويوازي بينهما وبين أقدار المستمعين، وبين أقدار الحالات، فيجعل لكل طبقة من ذللك كلامًا، ولكل حالة من ذللك مقامًا حتى يقســـ أقدار الكلام على أقدار المعاني، ويقسم أقدار المعاني على أقدار المقامات، وأقدار المستمعين على أقدار تلك الحالات" كما أشـارت البلاغة إلى ضرورة مر اعـــاة المــتهلم لظــروف الســـامع

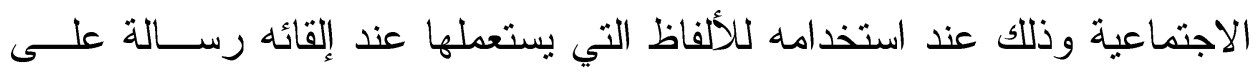
المخاطَب، بحيث لا يستخدم المخاطِب ألفاظًا غريبة على المستمع "فإن الوحشيْ 


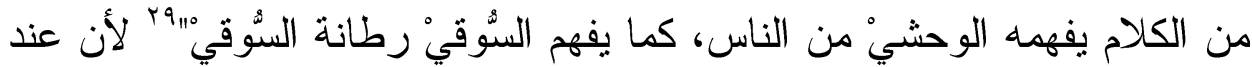
استخدامه لألفاظ لا تتاسب المستمع فسوف "تذهب فائدة الكــلام وتعـــدم منفعـــة

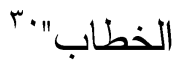

ونبّهت البلاغة أيضًا إلى ضرورة مر اعاة المتكلم للناحية السياسية لــدى

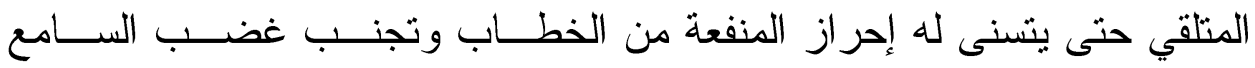
ومر اعاة حال السامع التي تستدعي الإفهام و التي تحدثّتا عنها في الفصــلـل الأول

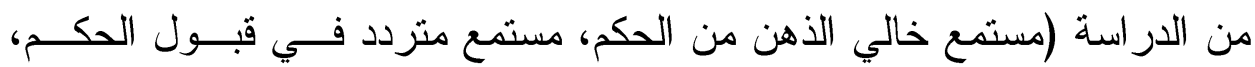
مستمع منكر للحكم) وكل مستمع يحتاج إلى أسلوب معيّن في مخاطبته. ومن هنا؛ تبرز فاعلية المخاطَب في العملية الإبلاغية التواصلية لأن الخطاب يُنتَجمن أجله لأنه "كما يحمل الخصائص التمبيزية للمتكلم فهو ينبّئ بطبيعة السامع الذي أُنشئ لإنه من أجله، بل أنّ الخطاب في ذاته يكون في أغلب الحالات حسـب مـــا يريــده السامع لا المتكلّم وتلك هي سمة اللسانيات التداولية الحديثة، التي تتقــاطع فيهـــا.

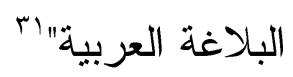
أمّا حديث التداوليون عن السامع فيتلخّص في قدرتــهـه علــى اســتقبال الخطاب وتفكيك معناه و إعادة بنائه بالاستتاد إلى العمليات الذهنية وفهمه لغرض

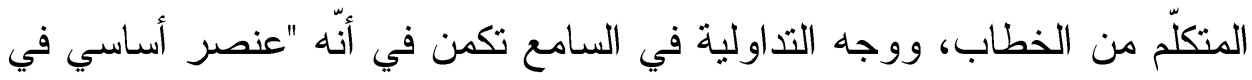

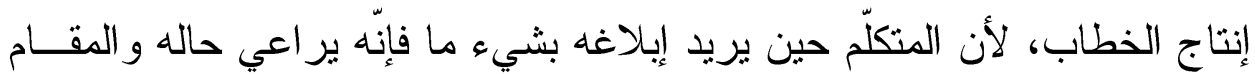
الذي هو فيه" إبه"

ومن هنا؛ نلاحظ أنّ البلاغة اهتمت بالمتكلم ووضعت له شروط ووسائل يستخدمها عند إنتاجه للخطاب تضمن له الاتصـال الناجح مــع المتلقـي فيصـلـل المعنى إلى قلبه و عقله ويؤثّ فيه ويحقق هدفه من الخطاب؛ "فالبلاغة في عمـق

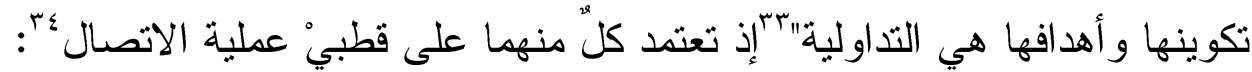




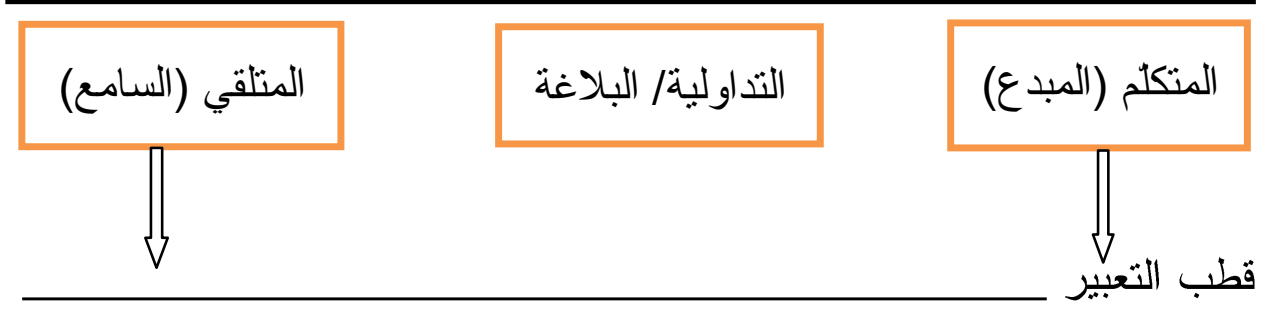

قطب التوصيل

فإذا كانت البلاغة ترمي إلى (التواصل) وتعتمد على مهارتيْ (الإقنــاع و الإمتاع) فإن التداولية تدرس أقطاب عملية التواصل من مرسيل ومرسل إليــه، ورسالة، وكذلك استر اتيجيات الخطاب المصاحبة لتلك العملية التو اصلية. وبتحليل خطب سبدنا عمر بن الخطاب اتضح لنا مدى وثوق الصلة بين أقطاب العملية التو اصلية (المرسيل- المرسل إليه- الرسالة) من وجهتي النظـــر البلاغية و التداولية، كما يتجلى في التحليل التالي لخطبة (أريد العدل و السوية!):

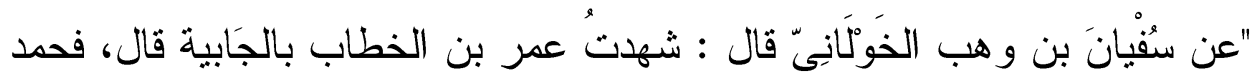

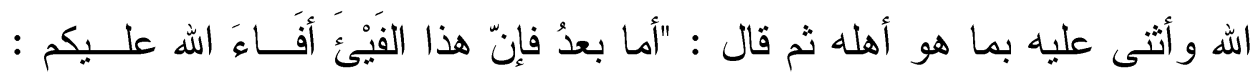

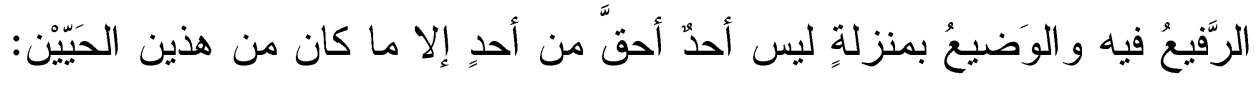

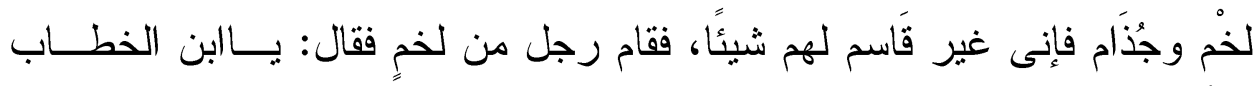

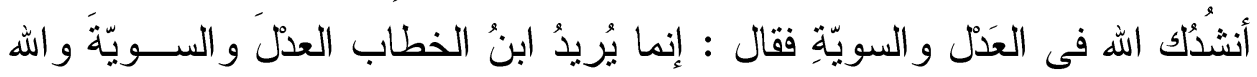

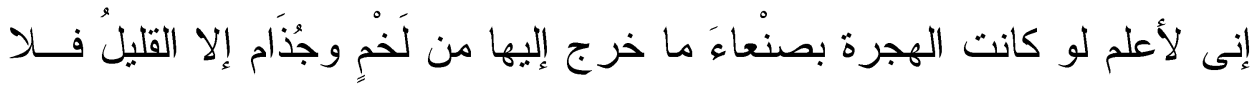

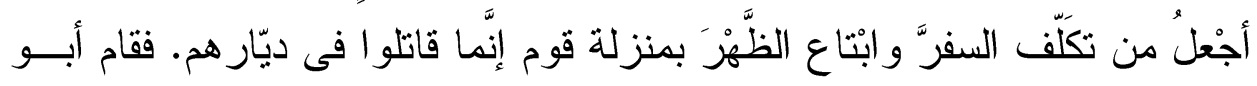

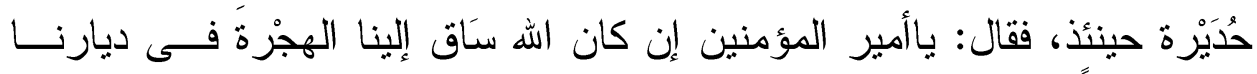

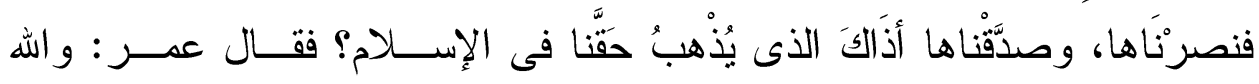

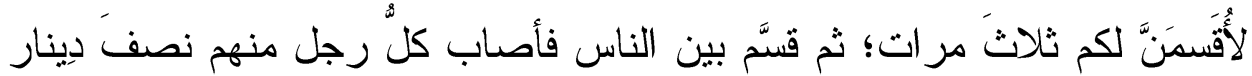


و إذا كانتُ معه امر أَتُهُ أعطاه دينارًا، و إذا كان وحْده أعطاه نِصفَ دينار، ثم دعا

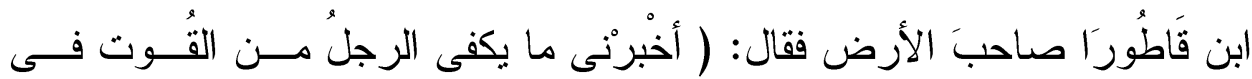

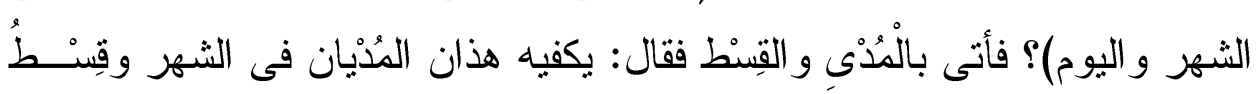

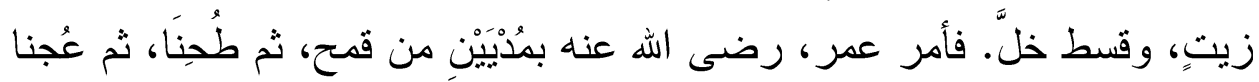

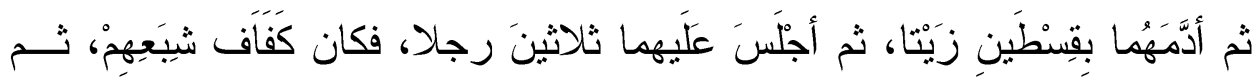

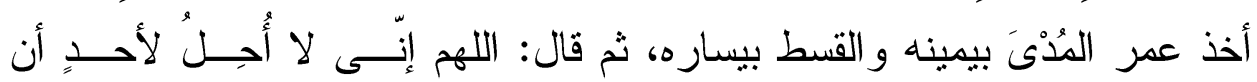

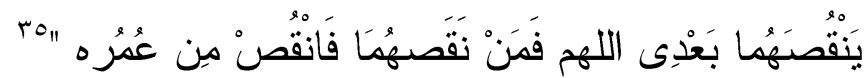

نجد فى الخطبة السابقة حوار بين المتكلم والمتلقى فالمتكلم (سيدنا عمر)

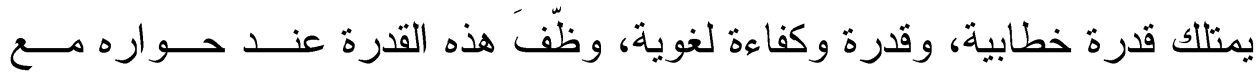

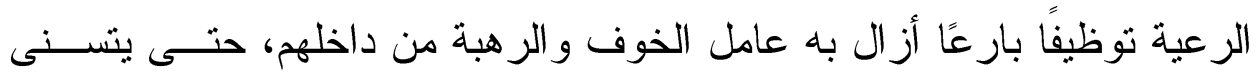
للمتلقى(المسلمين) استقبال الخطبة وتفكيك رموزها وشفر اتها لبلوغ مرمى المتكلم من الخطبة، ويمكن ملاحظة مر اعاة سيدنا عمر بن الخطاب لعدة نقاط أساســية ولية توضح بعض الثروط التداولية و الأهداف البلاغية الموجودة في الخطبة: 1-تتبه المتكلم إلى حسن اختبار الظرف المناسب لقول الخطبة. r-اختيار المتكلم للظرف المناسب ساعده على اختيار اللفظ المناسب و البعـد عن التكلّف وبالتالي، مر اعاة النفسية الملائمة للمتلقي.

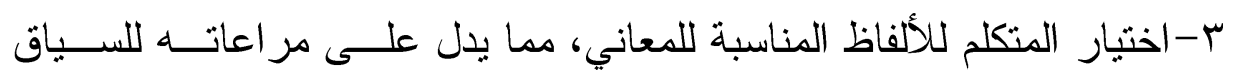
اللغوي الذي تُقال فيه الخطبة. ع-اختيار المتكلم للكلام المناسب الذي يوصل القصد ويرمي إلى المنفعة (نفعية (الخطاب) ه-مر اعاة المخاطِب (سيدنا عمر) لطبقات المخــاطَبين وحـــالاتهم واختيــار المعاني والألفاظ التي تتاسب كل طبقة (المقام) فلابد للخطيب أن يراعـي المقامات الخطابية وكل ما يتعلق بالمتلقي من ظروف سياقية وتو اصلية. ج-مر اعاة سيدنا عمر للأسس السابقة تمكّن من التأثير في المخاطَب و إيصــال هدف الخطاب وما يرمي إليه الخطاب إلى المخاطَب (الإقناع). 


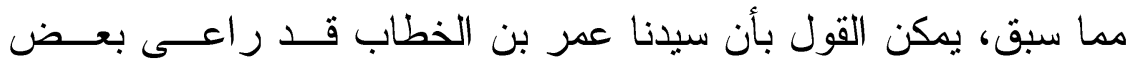

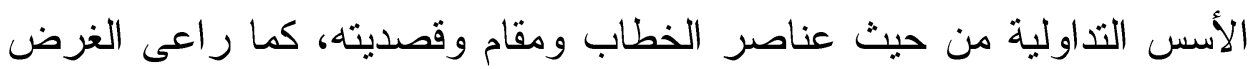

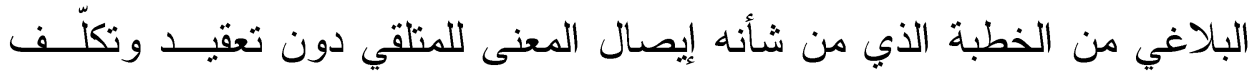
ليتحقق التواصل مع المتلقي.

\section{السياق التلاولي التطبيقي في خطب سيداثا عمر بن الخطابـ رضي اللّه عنه:}

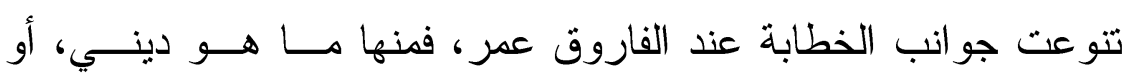

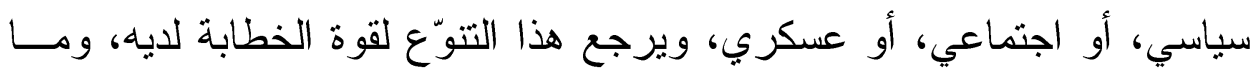

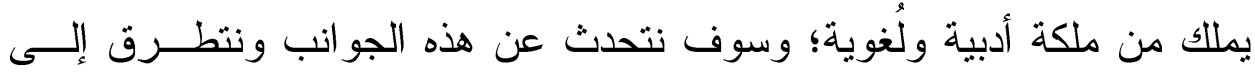
مقامات الخطابة عنده استنادًا إلى تصنيف (محمد العمري) لمقامات الخطابة الذي أورده في كتابه (بلاغة الخطاب الإقناعي) علمًا بأن هذا التصنيف وُجّهت إلبــهـ بعض الانتقادات لصعوبة التفريق بين الخطب السياسية و الاجتماعية و الدينيــة، فكثير" من الخطب التي ذُعيت اجتماعية يمكن اعتبار ها دينية أو سياسية، وهـــو الته مالمسناه بالفعل عند تصنيف الخطب، ولكنّا سنعتمد على تصنيف خطب ســبـنا عمر قدر الإمكان للضرورة المنهجية، وإنزال نصوص الخطب فـي مقامــات تو اصلية على النحو الآتي: 1- مقام الخطابة الدينية r- مقام الخطابة السياسية ب- مقام الخطابة الاجتماعية

\section{أولاً: مقام الخطابة الدينية عند الفاروقة الاجناعة عمر:}

لقد بلغت خطب سيدنا عمر بن الخطاب الدينية الذروة مــن الفصــاحة

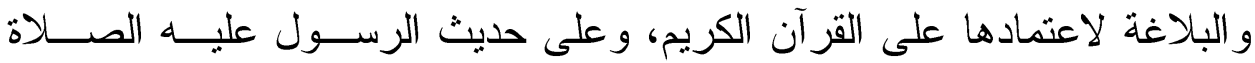
و السلام؛ ويعتبر مقام الخطابة الدينية أهم مقام تو اصلي عرفته الخطابة لارتباطه بموضو عات تتعلّق بالدين. ويُقسّم مقام الخطابة الدينية إلى ثلاثة أقسام: أ- مقام التعليم ب- مقام الوعظ - مقام المناظر ات المذهبية 
أ- مقام التعليم: - n يحرص المخاطِب في هذا المقام أن تكون العلاقة بينه وبين المخاطَب في حالة تقبل وتصديق و عادة ما يكون المخاطب في هذا المقام خالي الذهن يتقبــلـ المعرفة التي يلقيها إليه سيدنا عمر. ونذكر هنا بعض الخطب الدينية التي اتسمت بطابع التعليم، ومنها خطبة سيدنا عمر بن الخطاب عندما خطب لحجاج بيت الله الحر ام عند بــاب الكعبــة،

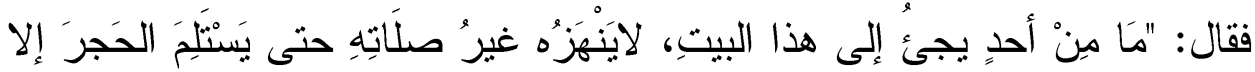

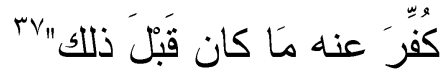
وقد تميزت الخطبة السابقة بالإيجاز المــؤدي إلـى توصــيل المعنـى للمخاطَب في أبسط صورة وباستخدام القليل من الألفاظ للتعبير عن الكثير مــن المعاني، وهو ما يدل على مر اعاة سيدنا عمر للسياق الذي يقول فيه خطبته، فقد

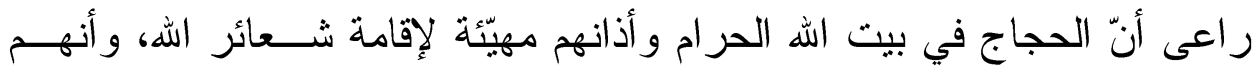
ليسوا بحاجة إلى الخطب الطويلة في ذلك الوقت.

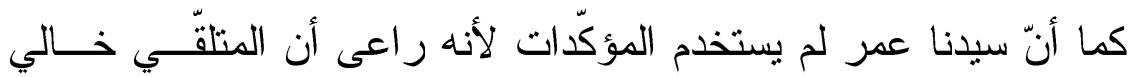
الذهن، مما يجعله يتقبل المعرفة الملقاه، ولا يحتاج إلى أساليب الإقناع و البرهنه، ولهذا غلب على هذا الصنف من الخطب الطابع التوجيهي و التربوي، فالخطابــة هنا "لا تهذف إلى ذكر معلومة ونقل معرفة كما أنها لا تقف عند تحقيق الغايــة

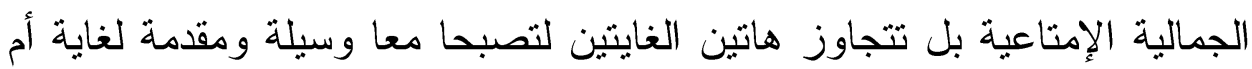
هي غاية التحول بهذه المعرفة وأساليب صباغتها إلى منجز سلوكي يحقق الغاية التربوية في الو اقع الفعلي" ئهي وتر اوحت خطب سيدنا عمر التعليمية بين الإيجــاز و الإطنــاب، ومــن الخطب التي استخدم فيها الإطناب لأن المقام يتطلّب التوضيح و الشرح،على سبيل الإيل

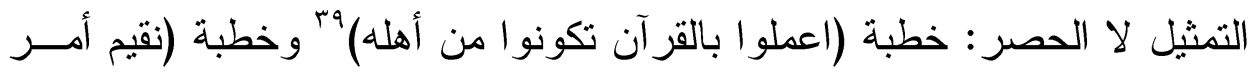

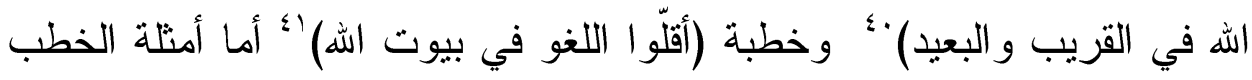
التي استخدم فيه الإيجاز : خطبة (عيد الفطر وعبد الأضحى) بك وخطبة (التحيات

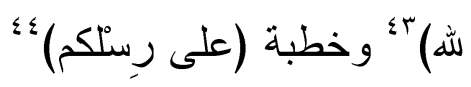




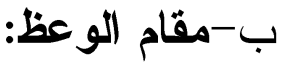

في هذا المقام يحاول المتكلم التأثير في المتلقي لحملهِ على تعديل سلوكه

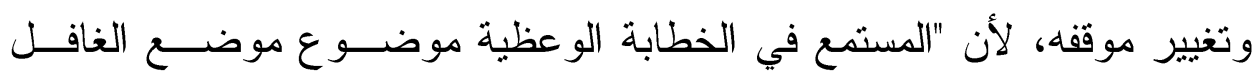

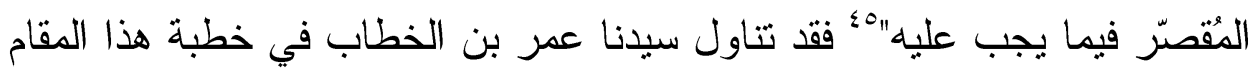

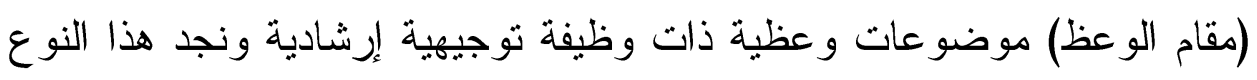

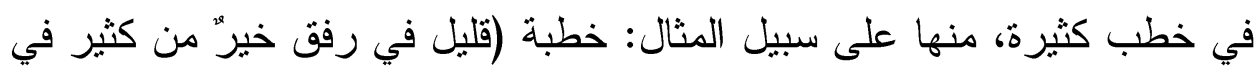

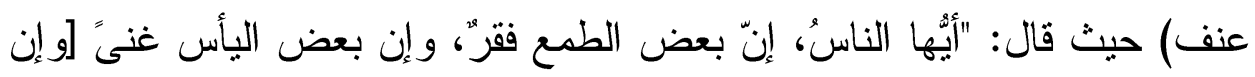

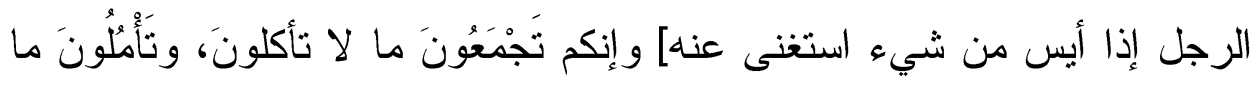

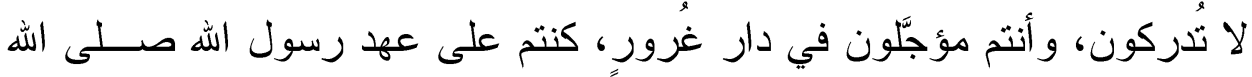

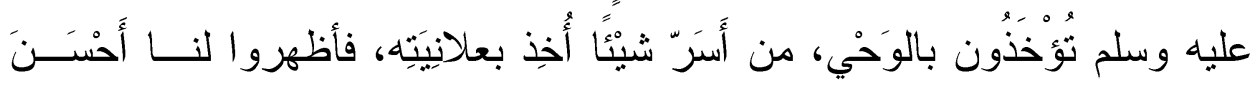

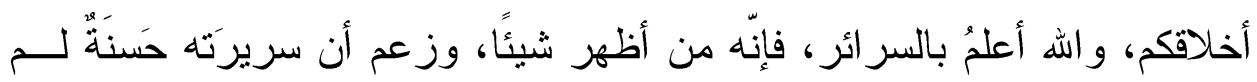

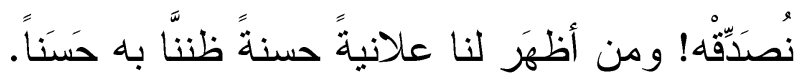

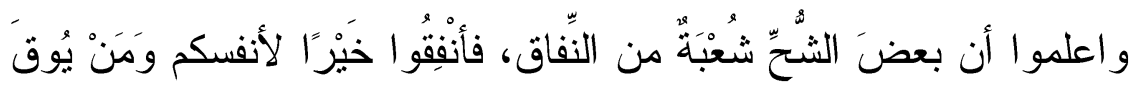

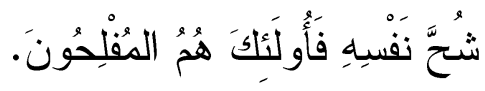

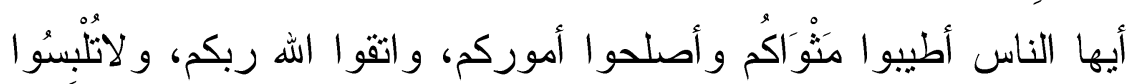

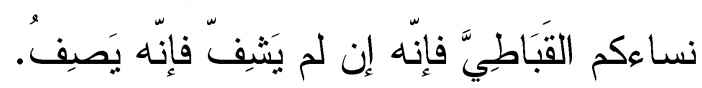

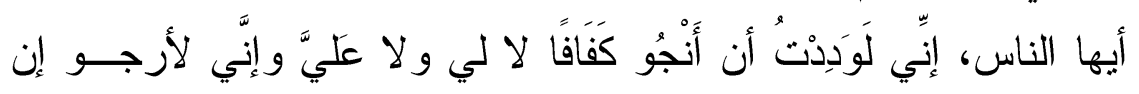

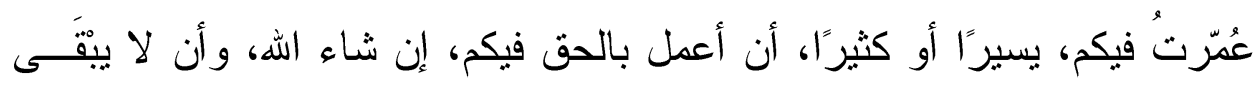

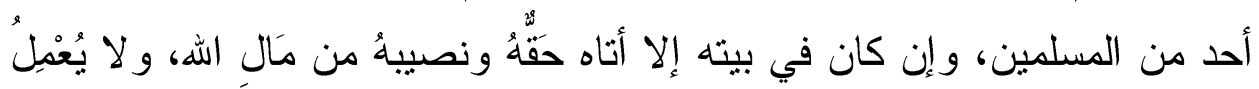

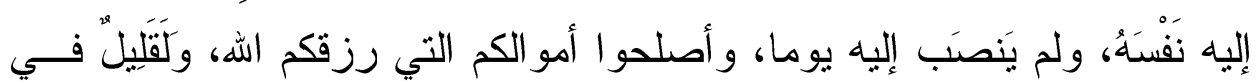

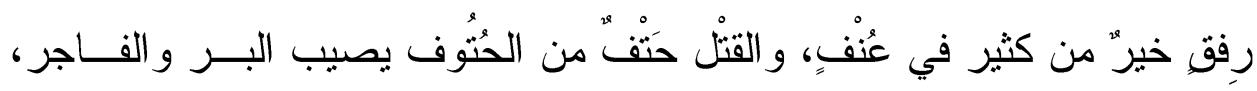

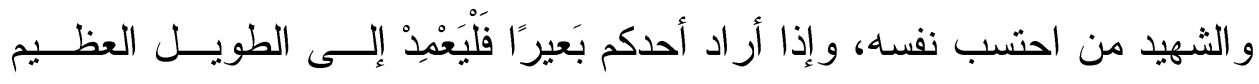

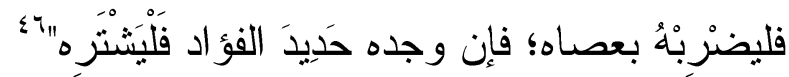


استخدم سيدنا عمر بن الخطاب في هذه الخطبة أسلوب التأكيد في أكتــر

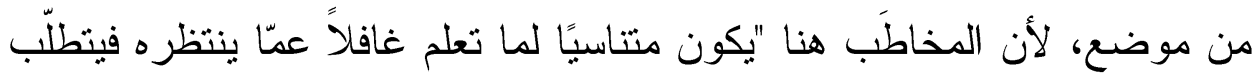

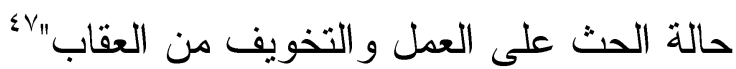

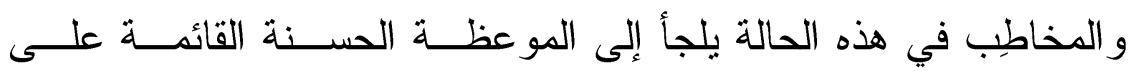
التزغيب و التزهيب في الوقت نفسه، ويحث المتلقي على العمل الصالح من أجل الفوز بالدنيا والآخرة، ويحذر من الطمع والشّح الذي يُورث الندم و الحرمان من

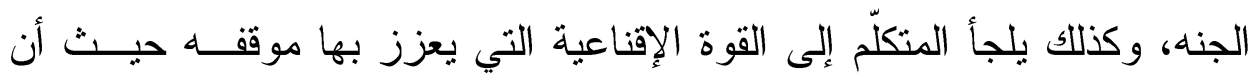
المقام يتطلّب استخدامه للأسلوب الإقناعي، بذكر الأدلة و البر اهين الو اقعية.

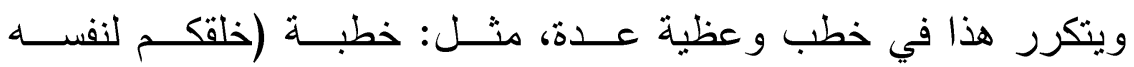

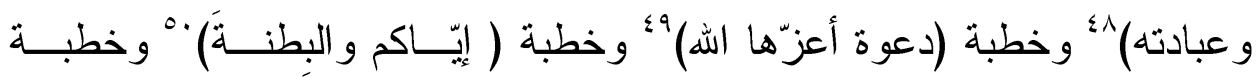
(اعملو ا بالقرآن تكونوا من أهله) 'ونجد في كل ذلك أن المتكلم (ســيدنا عـــر) يجمع في الخطب الدينية بين مقاميّ الوعظ و التحليم. ج- مقام المناظر ات المذهبية:

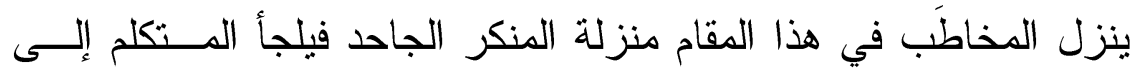
استخدامه للحُج العقلية و النقلية التي تتناسب مع عقلية المتلقي وتتناسب أيضًا مع السياق الذي يقول فيه الخطبة.

و هنا يجب على المخاطِب توكيد (الأمر) الذي يتحدّث عنه في الخطبــة للمتلقي بقدر إنكاره قوة وضعفًا، ونجد هذا النوع في أكثر من خطبة، مثل خطبة

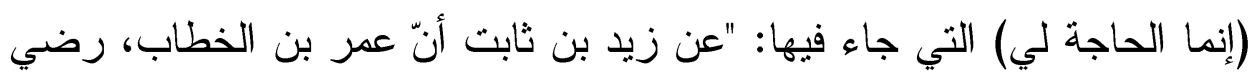

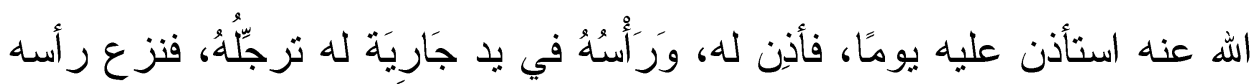

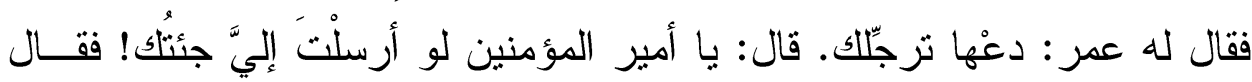

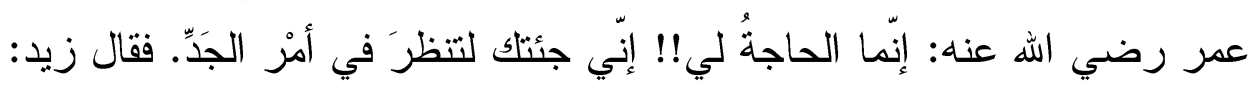
لا و الله ما يقول فيه. فقال عمر، رضي الله عنه: ليس هو بوحْي حتى نَزِيـــــ أو

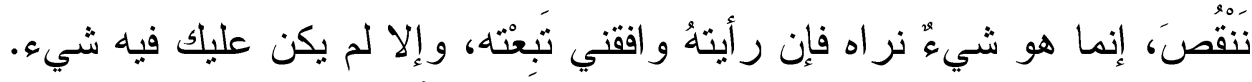

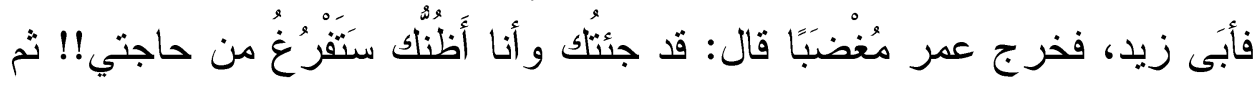


أتاه مَرَّةً أخْرى في الساعة التي أتاه المرة الأولى فلم يَزلْ به حتى قال: فسأكتبُ

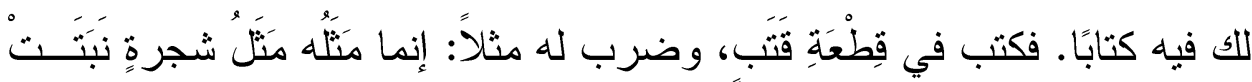

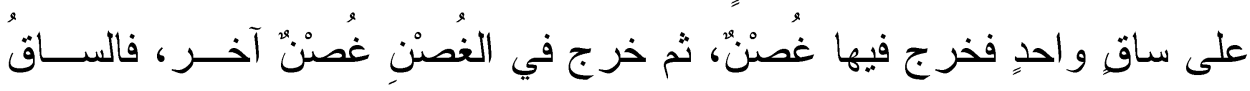

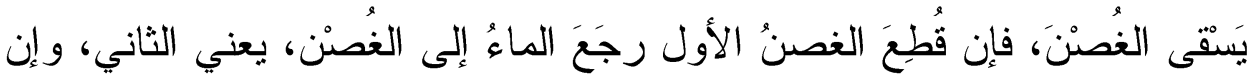

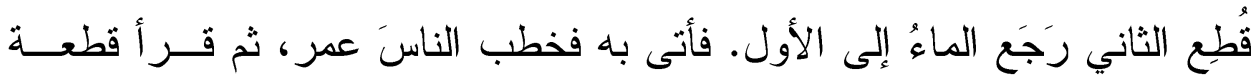
القَتب عليهم ثم قال: إن زيد بن ثابت قد قال في الجد قو لا و أنا أمضــيته. قــــال:

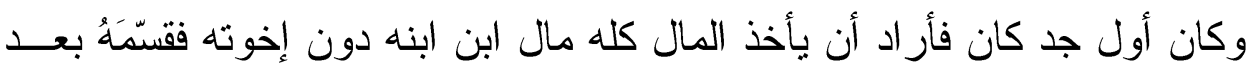
ذلك عمر بن الخطاب" وابه يلاحظ هنا أن المقام مقام مناظرة، لكن سيدنا عمر في هذا المقام كــان يعتمدعلى الحوار بينه وبين المتلقي خال من الإنكار بل كان المخاطَب يراجعـــ

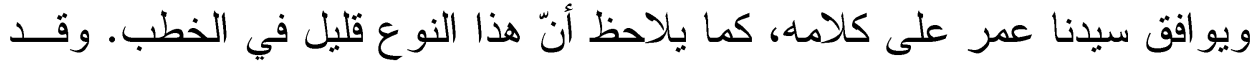
راعى سيدنا عمر في خطبه المواعمة بين الطبيعة الدينية لخطبه، وبين الســياق الخارجي الذي تُقال فيه

\section{ثاثيًا: مقام الخطابة السياسية عند عمر بن الخطاب}

بلغت الخطب السياسية في عهد عمر بن الخطاب أوجها فجاءت خطبـــه مليئة بالجو انب السياسية و هذه الخطب مختلطة أحياناً بالمعاني الدينبــة وأحيانـــا أخرى ممزوجة بالجانب الحربي، والاقتصاي، بحيث تجعـل المتلقـي مســتعدًا لاستقبالها و الاقتناع بها. ويندرج تحت الخطابة السياسية أ- جميع الخطب المتعلقة بالعمل في سبيل بناء الدولة أو بسنط نفوذها: نشأت الخطابة السياسية عند سيدنا عمر مرتبطة بقضايا الدين و العقبــدة وشكلت أبرز مقامات التو اصل الإقناعي حيث تتاولت قضايا لصيقة بحياة الناس اليومية ومتعلقة بالعمل في سبيل بناء الدولة سو اء كان هذا المقام مقام جهـاد أو مقام طاعة أو مقام عصيان أو غير ذلك. 
و نلمس هذا النوع بكثرة في خطب سيدنا عمر بن الخطاب، ومن أمثلـــة

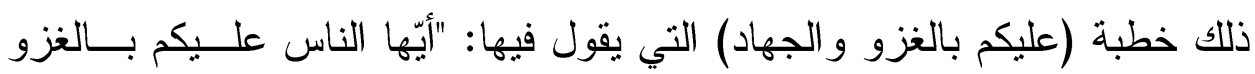

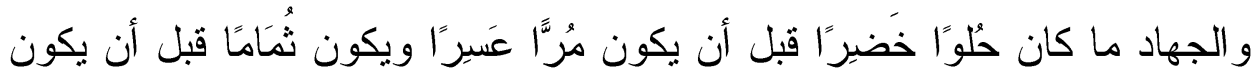

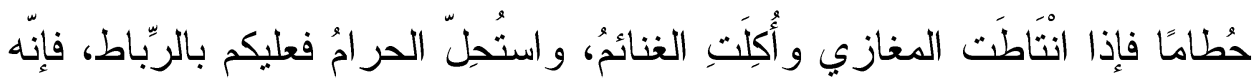

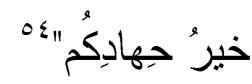

يحث المخاطِب في هذا المقام الخطابي الرعيةعلى الجهاد في ســبيل اله

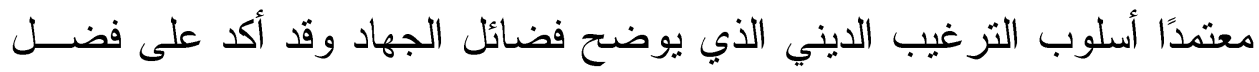

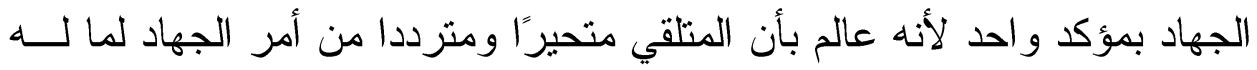

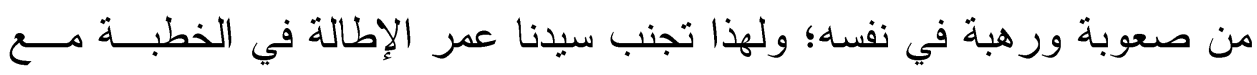
توظيف مفرداته و عبار اته كي تتضافر لأداء الغاية التي يريد توضيحها من خلا ونل خطبته كما راعى السياق الخارجي للخطبة فجاءت موجزة مر اعية لنفسية المتلقي

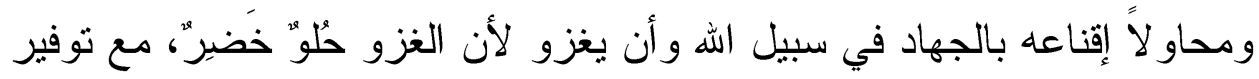

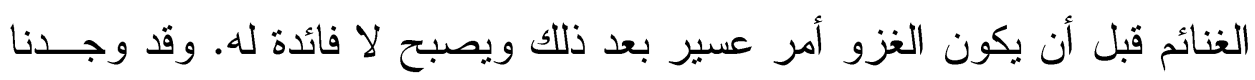

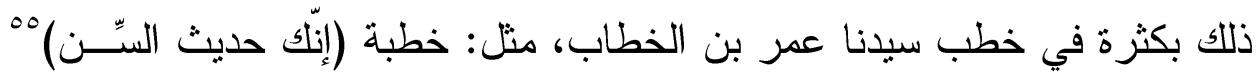

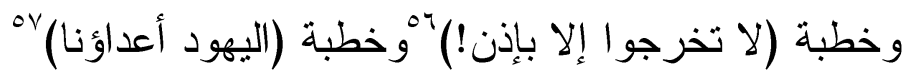

\section{ب-خطب الصراع حول الخلافة والحكم داخل المجتمع الإسلامي:}

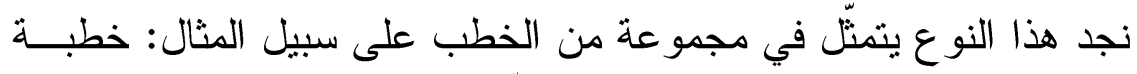

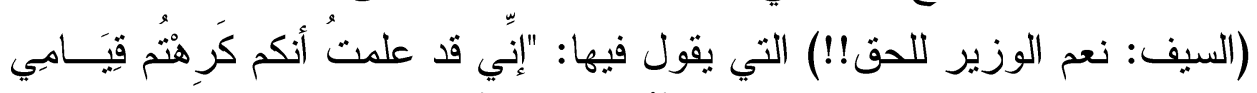

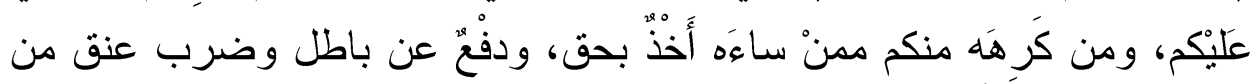

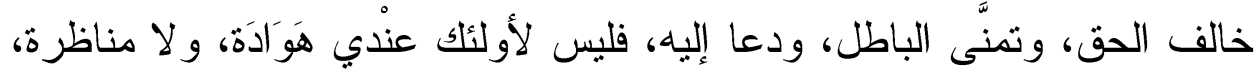

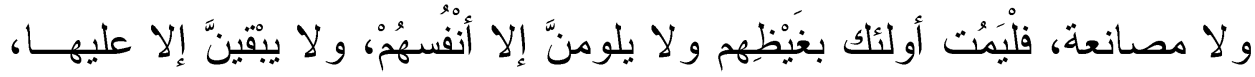

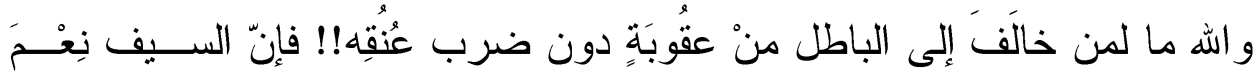

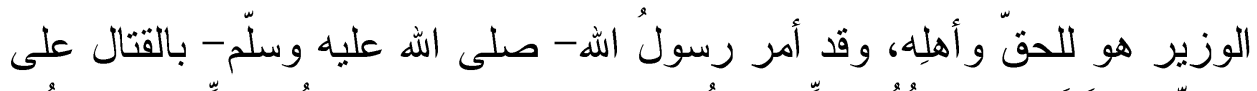

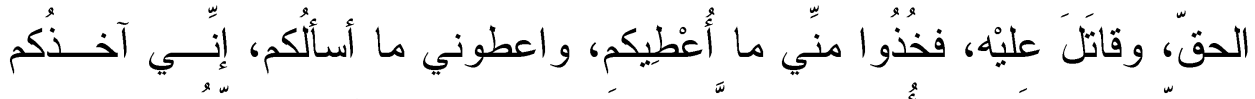

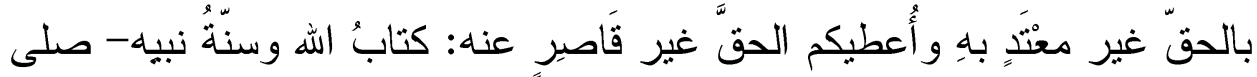

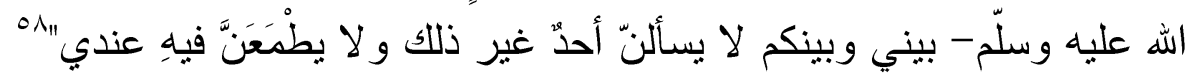


وظّف سيدنا عمر هذه الخطبة توظيفًا بارعًا إذ استخدم كل ما جاش بــه

صدره من دفاع عن رأيه، وشرحه لمنهجه السياسي الذي يتعامل به. ويوجه خطبته إلى مخاطَب ر افض للحكم وليس لديه قبول لهنه، لذا وجنه

عليه توكي خطبته بأكثر من مؤكد ونجد المقام الخطابي هنا مقام إطالة لأنه أر اد وداد

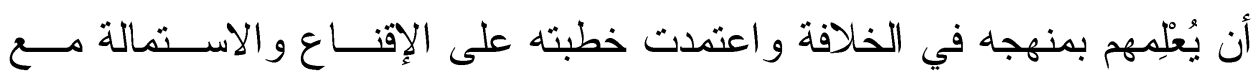

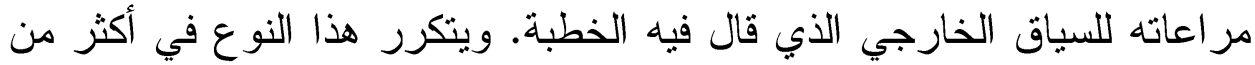

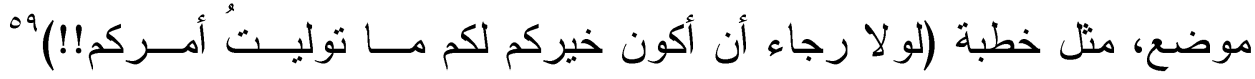

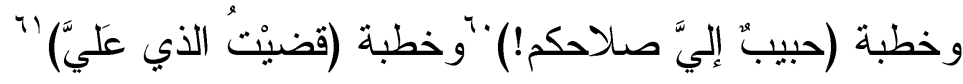

\section{ثالثاّ: مقام الخطابة الاجتماعية عند عمر بن الخطاب:}

يدخل فى هذا المقام الخطابى خطب المشاركة الوجدانية فــى الأحــزان

و المسر ات، وخطب الأملاك و المخاصمات القضائية و غير ها.

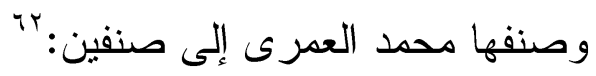

أ-خطب فى موضوعات اجتماعيةتنتاول العلاقة بين الناس وتنظيم المجتمع مثل خطب الأملاك، والصلح و المخاصمات القضائية وهى فى أغلبها ذات طبيعـة

\section{موضوعية:}

ويسعى المخاطِب فى هذا النوع من الخطب إلى توضيح العلاقــة بــين

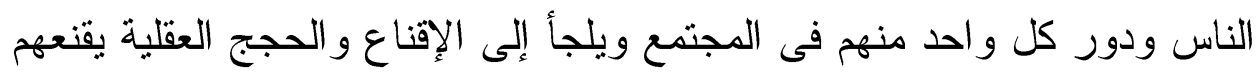
بتنفيذ أوامره. ونجد هذا النوع من الخطب فى أكثر من خطبة لسيدنا عمر بـن الخطاب مثل خطبة (ابتليت بكم و ابتليتم بى !!) خطب عمر بن الخطاب فَحَمِدَ الله

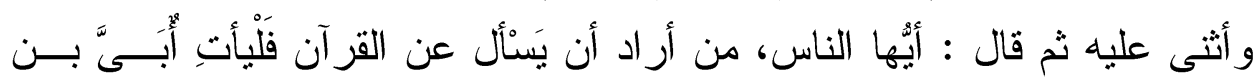

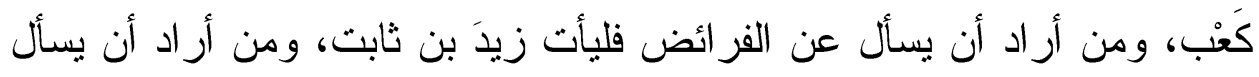

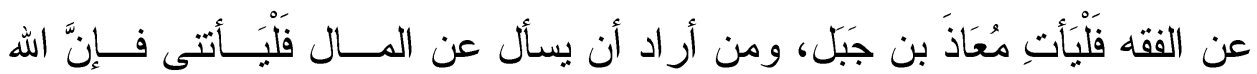

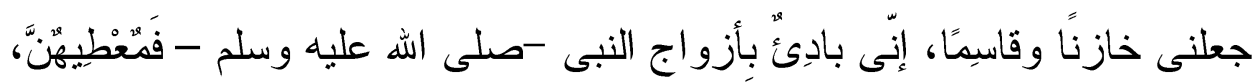

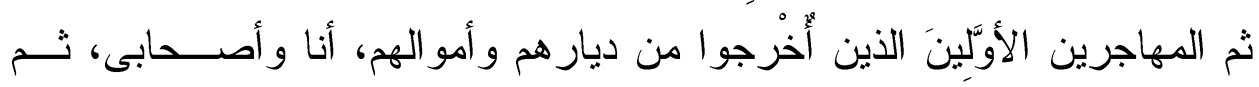

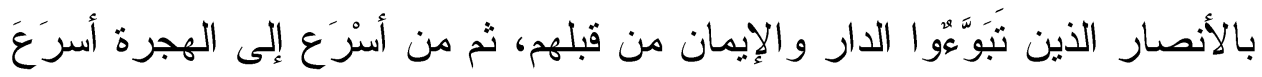




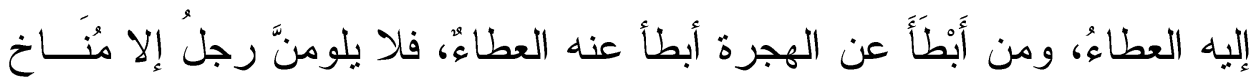

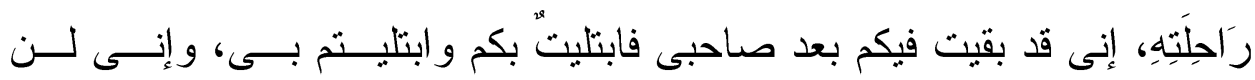

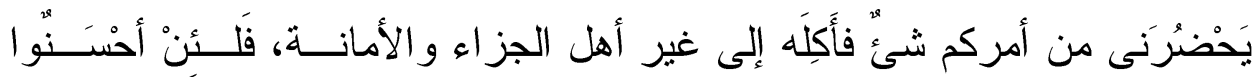

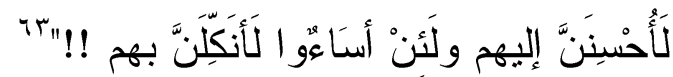

هذه الخطبة ذات موضوع اجتماعى تتناول تتظيم المجتمع وتحديد مهـام

كل فرد، وقد وفق فيها سيدنا عمر بن الخطاب عند استخدامه لقصـر الكلمــات التهات

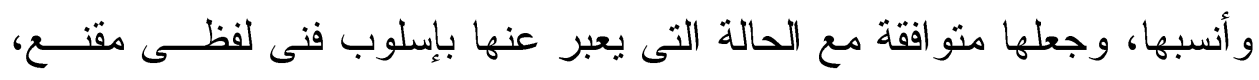

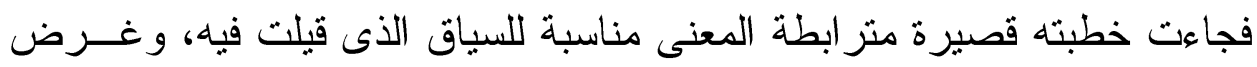

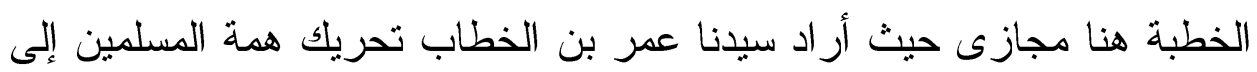
الهجرة لينالوا العطاء الكثير؛ وجاءت الخطبة مؤكدة بأكثر من مؤكد لأن المتكلم عالم بحال المسلمين فى ذلك الوقت وكثرة اعتر اضهم على أمور توزيع المال.

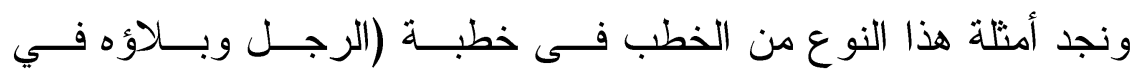

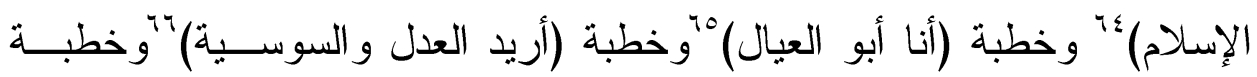

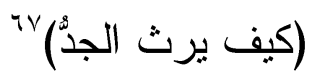

ب- خطب ذات طبيعة وجدانية هدفها المثــاركة والإثــراتك فــى المســرات

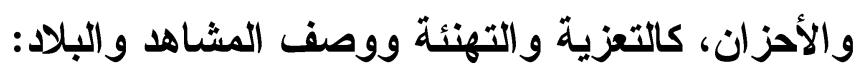

فى هذا النوع من الخطب يكون الدقام الخطابى مقام تأثير و استمالة لأن

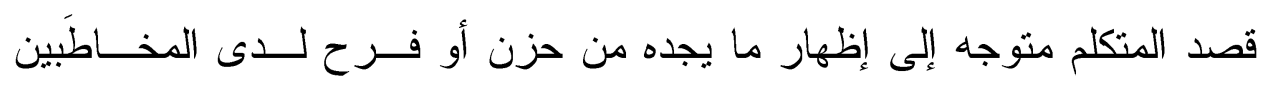

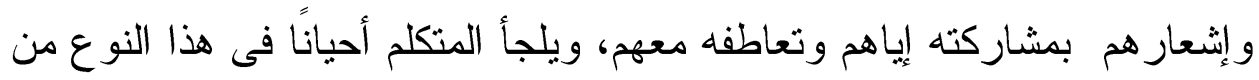

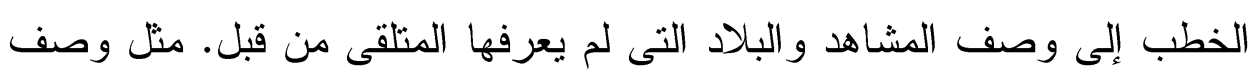

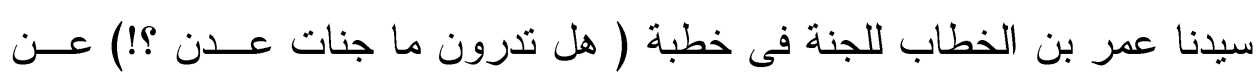

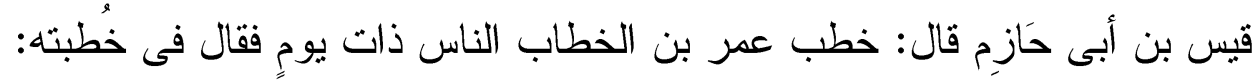

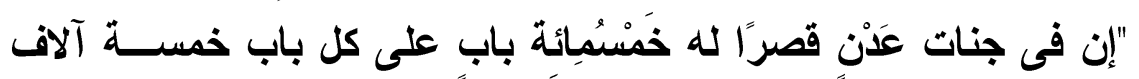

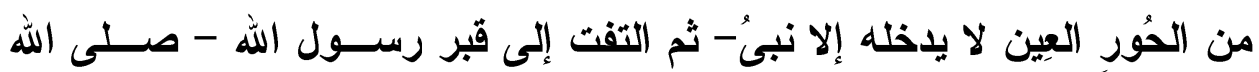

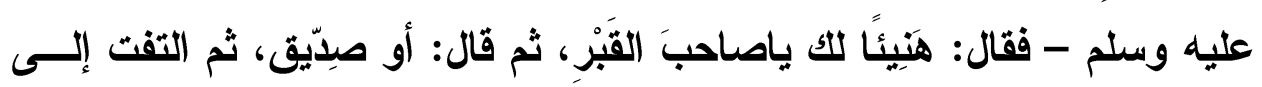


قبر أبى بكر فقال: هنيئًا لك يأبا بكر ثم قال: أو شَهَيد- ثم - أقبلَ على نفسـهـ

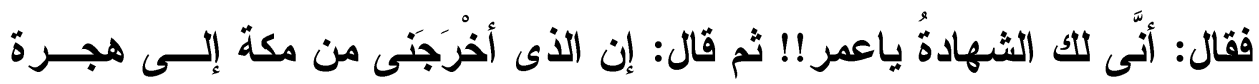

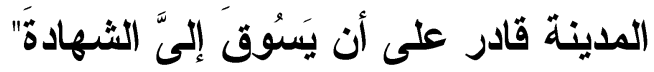

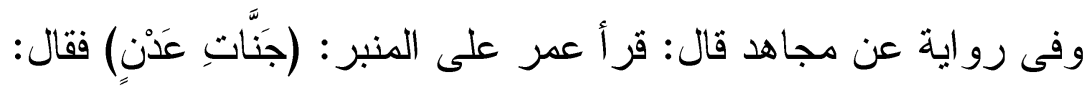

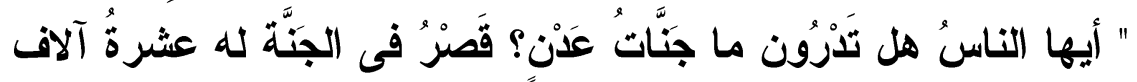

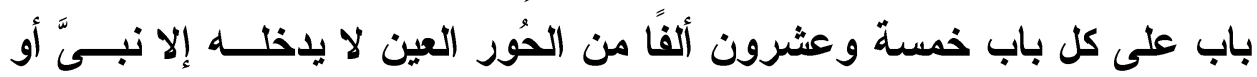

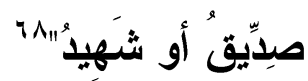
وصف سيدنا عمر بن الخطاب الجنَّة للمخَاطبين ولم يســنخدم أســلوب

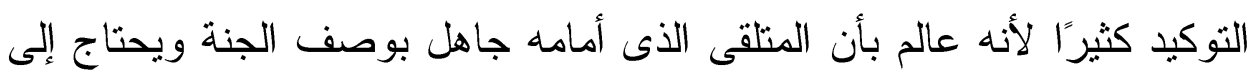

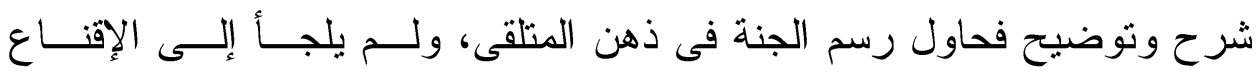
أو الاستخلال لأن الخطبة هنا تقتضى مقام المشاركة الوجدانية وإثعار المتلقى أنه النها

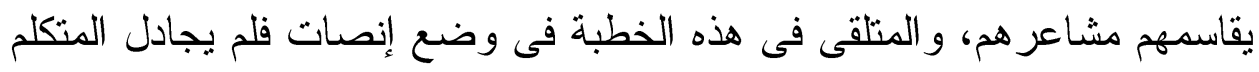
لأنه مشتاق لسماع وصف الجنة النى لم يعرفها.

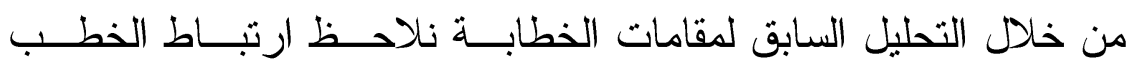

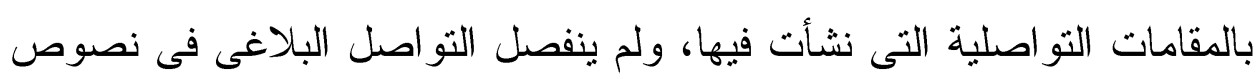
هذه الخطب عن المقاصد التداولية التى تحرك أطراف العملية التواصلية . فإذا كان الغرض البلاغى فى هذه الخطب هو الإقناع الجمالي و التـأثير

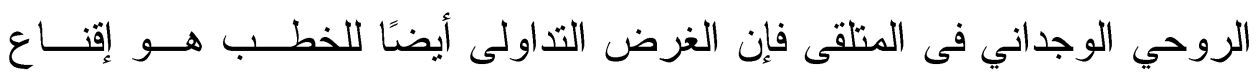

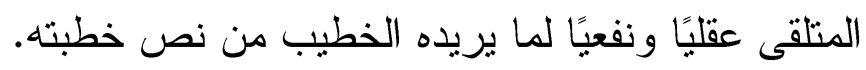

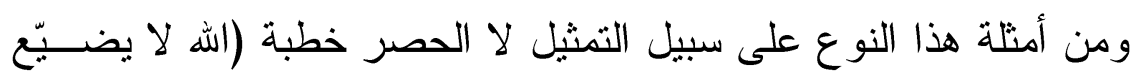

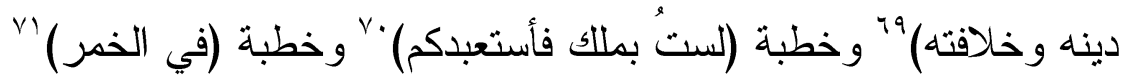

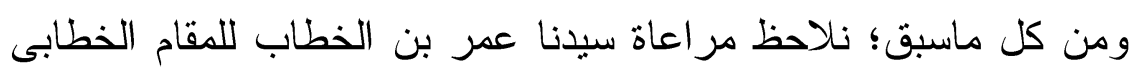

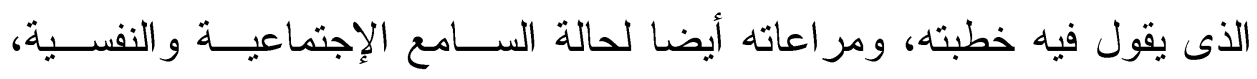

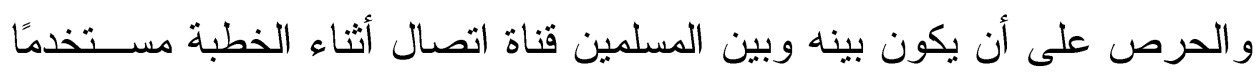
قدرته اللغوية و التخاطبية حتى يصل إلى إقناع المتكلم بغرضه من الخطبة لفئه 


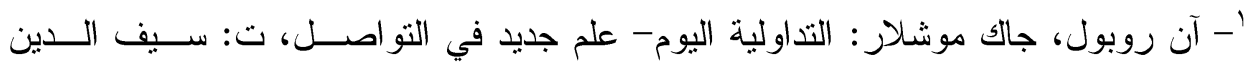

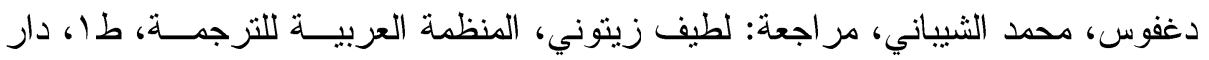

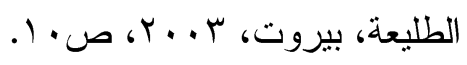

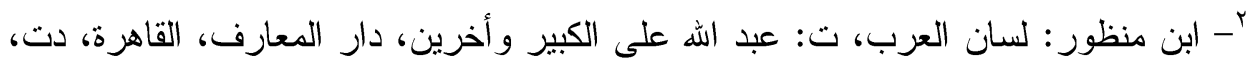

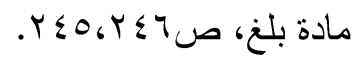

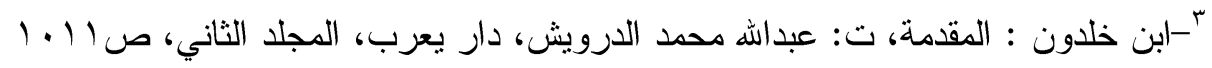

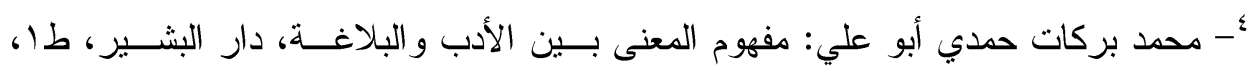

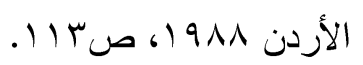

×- السكاكي: مفتاح العلوم، ت: عبد الحميد هنداوي، دار الكتب العلمية، طا، بيروت ، لبنان

$$
\begin{aligned}
& \text { ص • ص . }
\end{aligned}
$$

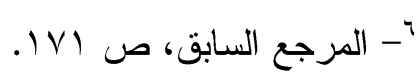

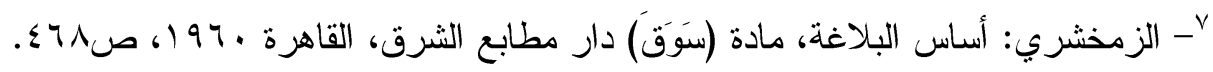

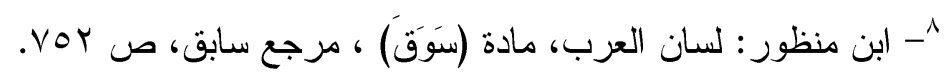

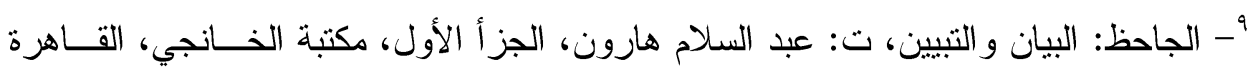

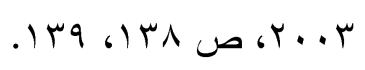

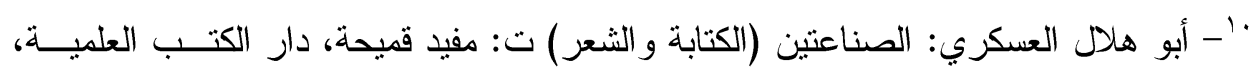

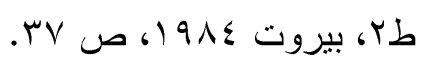

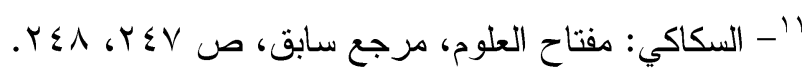

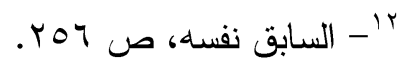

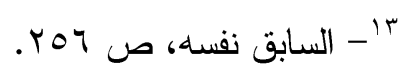

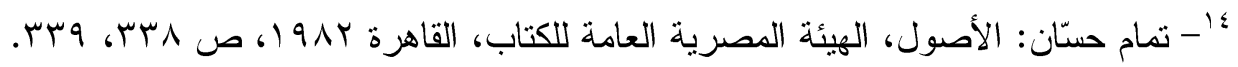

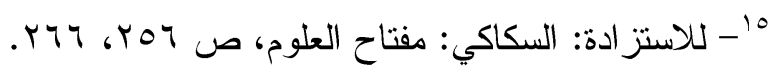

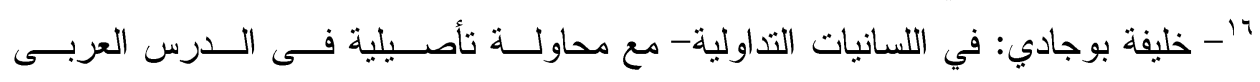

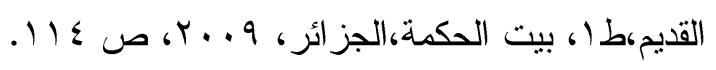

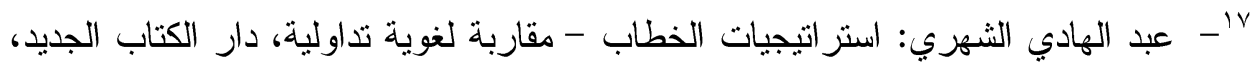

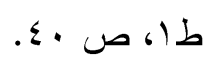

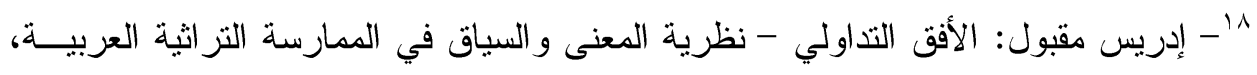

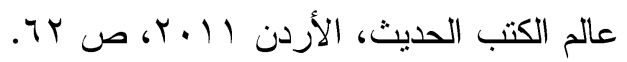




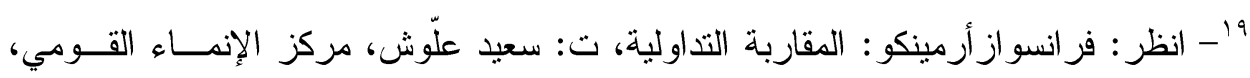

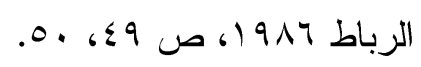

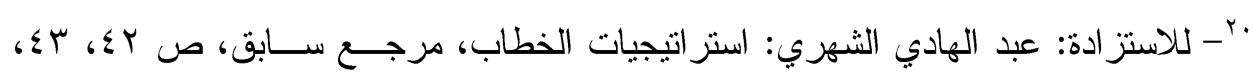

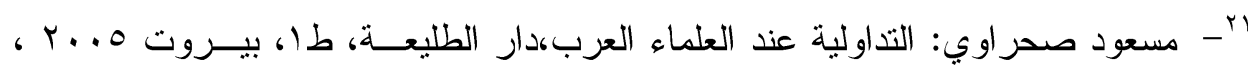

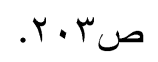

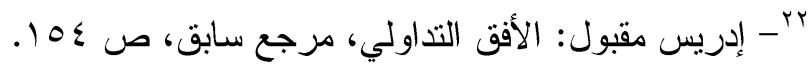

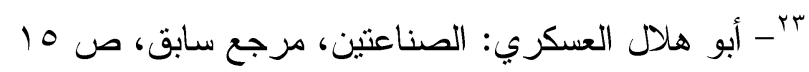

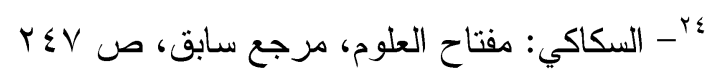

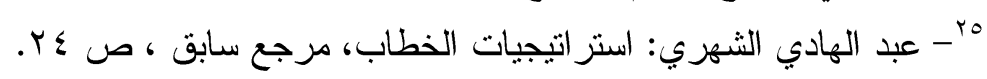

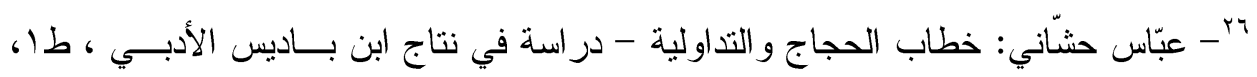

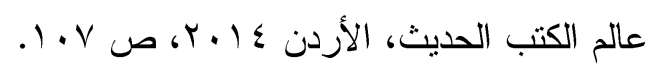

Y

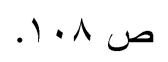

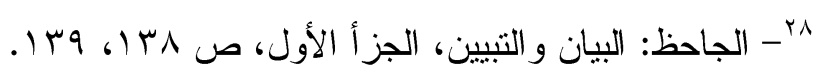

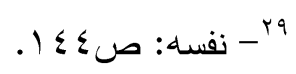

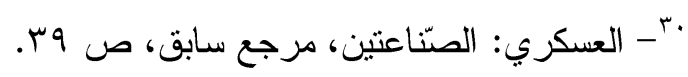

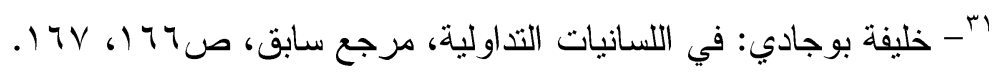

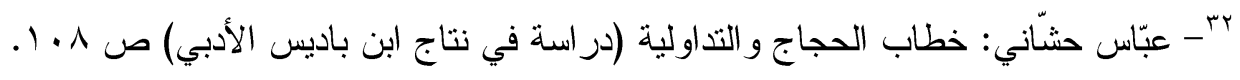

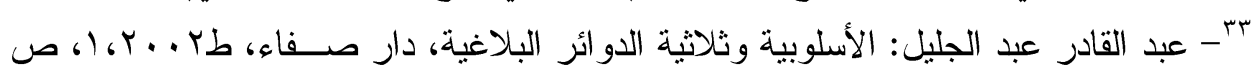

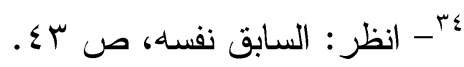

0ro - محمد أحمد عانشور: خطب أمير المؤمنين عمر بن الخطاب رضي اله عنه ووصاياه، دار

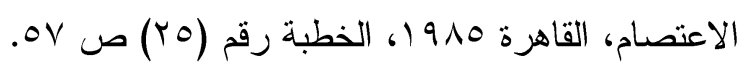

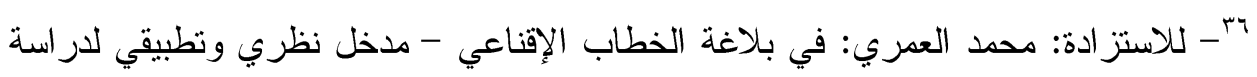

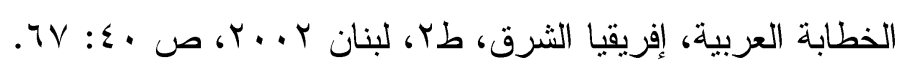

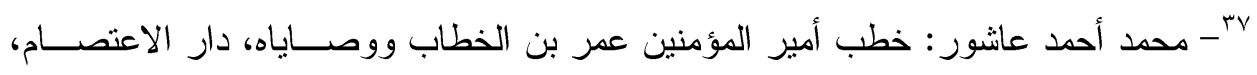

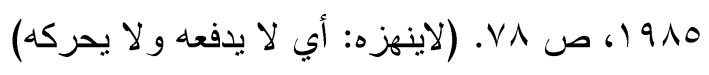


يَّ- عيد بلبع: السياق وتوجيه الدلالة مقدمة في نظرية البلاغــة النبويــة، بلنســية للنشـر

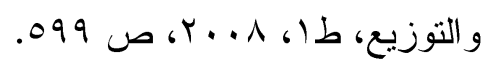

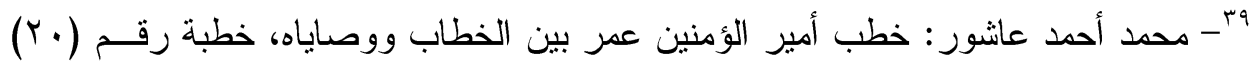
ص ص

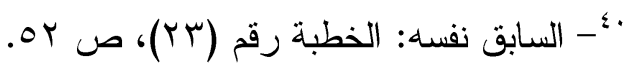

$$
\begin{aligned}
& \text { I؛- السابق نفسه: الخطبة رقم (9 §) ص }
\end{aligned}
$$

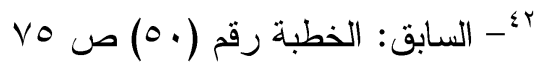

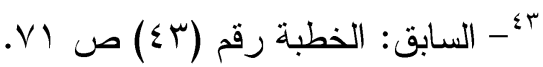

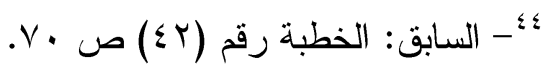

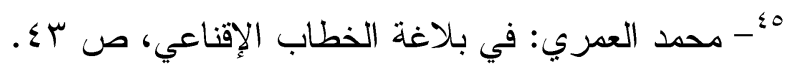

ب؛- محمد أحمد عاشور: خطب أمبر المؤمنين عمر بن الخطاب ووصاياه، الخطبة رقم (· (1) ص هم. ـ القباطيّ: جمع قبطية، وهي ثياب من كتان بيض رقاق كانــت تتســج بمصــر

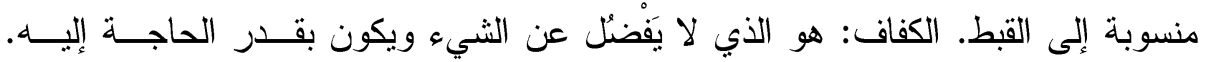
الحتف: الهلاكك. حديد الفؤاد: أي شديداً نشيطاً.

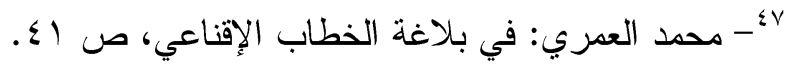

1؛ـ محمد أحمد عاشور : خطب أمير المؤمنين عمر بن الخطاب ووصاياه، الخطبة رقـم (7) ص מ

9؛- السابق نفسه: الخطبة رقم (1 ا) ص بــ.

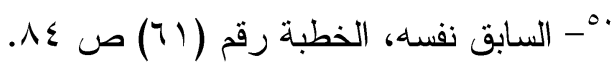

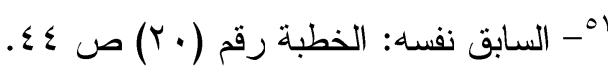
ro- المرجع السابق، الخطة رقم (VV) ص • ^. ترجله: أي تسرح شعر رأسه وتتظفه. القتب: الرحل الصغير على قدر سنام البعير ·

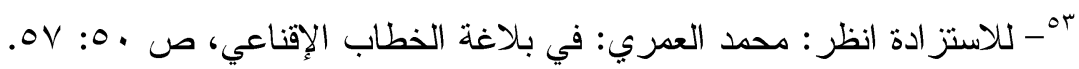
؛ْ- محمد أحمد عاشور: خطب أمير المؤمنين عمر بن الخطاب رضي الله عنه، الخطبة رقم

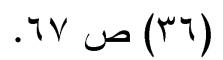

00- السابق نفسه: الخطبة رقم (YT) ص OV.

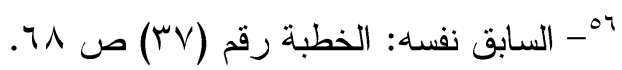

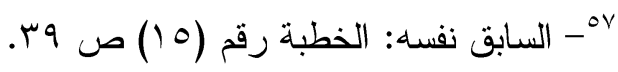




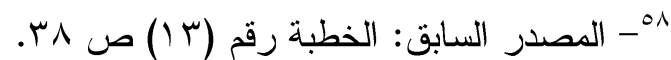

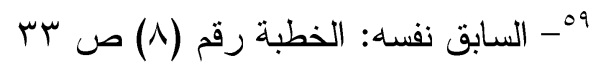

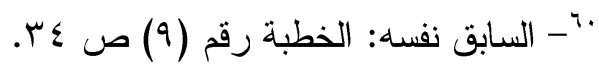

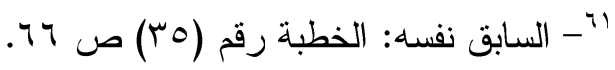

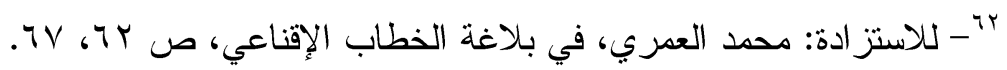

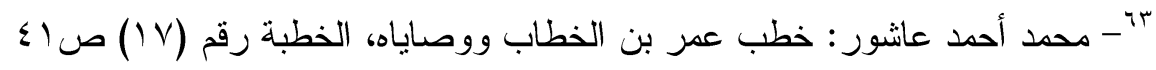

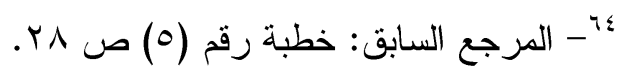

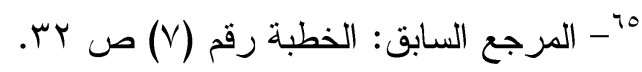

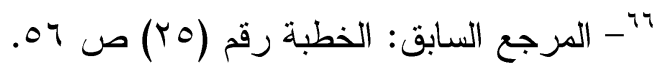
VV

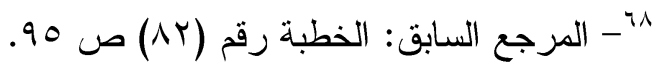

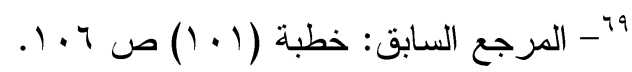

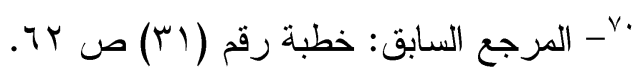

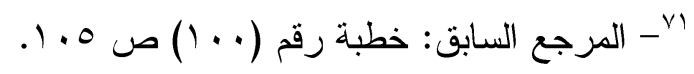

